\title{
SLAMF6 in Health and Disease: Implications for
}

\section{Therapeutic Targeting}

Burcu Yigit ${ }^{1,{ }^{*}}$ byigit@bidmc.harvard.edu, Ninghai Wang ${ }^{1}$, Roland W. Herzog ${ }^{2}$, Cox Terhorst ${ }^{1, *}$ cterhors@bidmc.harvard.edu

'Division of Immunology, Beth Israel Deaconess Medical Center, Harvard Medical School, Boston, MA, USA.

${ }^{2}$ Herman B Wells Center for Pediatric Research, Indiana University School of Medicine, Indianapolis, IN, United States

"Corresponding authors at: Beth Israel Deaconess Medical Center, Harvard Medical School, 3 Blackfan Circle, Center for Life Sciences, Room CLS 928, 02115, Boston, MA USA.

This is the author's manuscript of the article published in final edited form as:

Yigit, B., Wang, N., Herzog, R. W., \& Terhorst, C. (2018). SLAMF6 in health and disease: Implications for therapeutic targeting. Clinical Immunology. https://doi.org/10.1016/j.clim.2018.10.013 


\section{Introduction}

Effective immune responses develop after a well-orchestrated series of events that include recognition, immune cell interactions and activation/inhibition of signaling pathways. The signaling lymphocyte activation molecule family (SLAMF) of cell surface receptors, which consists of nine transmembrane proteins (SLAMF1-9) expressed at different levels, are involved in viral and bacterial recognition, serve as co-stimulatory molecules at immune synapses, and modulate myeloid and lymphocyte development. SLAMF receptors are homophilic receptors, with the exception of SLAMF2 and SLAMF4, and are only expressed on hematopoietic cells. Their adaptors, SLAM associated protein (SAP) and Ewing's sarcoma-associated transcript 2 (EAT-2), bind to the cytoplasmic tails and control the functions and magnitude of SLAMF receptor signaling. In this review, we focus on the current knowledge on the role of SLAMF6 receptor in regulating immune functions and recent findings describing how SLAMF6 can be exploited as a target in human malignancies. 


\section{A Background of the SLAM Family Members and adaptors SAP and EAT-2}

\subsection{Structure}

The SLAM family of immune cell surface receptors is a member of the CD2 subfamily of the immunoglobulin (Ig) superfamily consisting of nine members, SLAMF1-9 [1-4]. SLAMF receptors are type I transmembrane glycoproteins comprised of an extracellular membrane containing an N-terminal V-Ig domain followed by a C2-Ig domain in the extracellular region (this set is duplicated in SLAMF3), a transmembrane region, and an intracellular cytoplasmic tail containing tyrosine based switch motifs (ITSM). Notable exceptions to this structure include SLAMF2, which has a glycosyl-phosphatidyl-inositol (GPI) membrane anchor and like SLAMF8 and SLAMF9 lack ITSM motifs [5-8]. Binding of SLAM associated adaptors; SAP and EAT-2, to cytoplasmic tails of various SLAMFs regulate their function on different immune cells. Expression of SLAMFs and their adaptors is restricted to hematopoietic cells. In addition, the gene loci are located on chromosome 1 in both mice and humans, except SAP, which is located on the $\mathrm{X}$ chromosome [9](Figure 1).

All SLAMFs are homophilic receptors aside from SLAMF2 and SLAMF4, which bind each other [10-12]. The determination of the SLAMF3, SLAMF5 and SLAMF6 crystal structures revealed in-trans interactions through their IgV domains (SLAMF3 unpublished data, generously donated by Profs. Steve Almo and Stanley Nathenson, Albert Einstein College of Medicine (Figure 2) [13, 14]. Engagement of SLAMF 
receptors on immune cells (e.g. APC - T cell) trigger inhibitory or activating signals that modulate cellular responses. Within these homophilic and heterophilic interactions, the binding affinities for each SLAMF varies (SLAMF3 nM, SLAMF5 sub- $\mu$ M, SLAMF6 $2 \mu \mathrm{M}$, SLAMF2/4 4 $4 \mathrm{M}$, SLAMF1 $\sim 200 \mu \mathrm{M})$ which likely contributes to functional differences within the family of receptors [12-15]. In addition to being self-ligands, SLAMF1 also serves as an entry receptor for Measles virus [16, 17] while SLAMF1, SLAMF2 and SLAMF6 have been demonstrated to interact with bacterial components [18-21] (reviewed in detail ref [22]).

\subsection{SAP and X-linked Lymphoproliferative Disease (XLP)}

First identified in 1975, X-linked lymphoproliferative disease (XLP) (also known as Duncan's disease) is an extremely rare primary immunodeficiency that mainly manifests in males and is primarily characterized by extreme susceptibility to infection with Epstein-Barr virus (EBV) [23]. However, most XLP patients infected with EBV develop fatal or fulminant infectious mononucleosis due to dysregulated immune responses, which leads to clonal proliferation and expansion of $\mathrm{T}$ and $\mathrm{B}$ cells. NK and $\mathrm{CD}^{+} \mathrm{T}$ cell functional defects have been identified in XLP patients likely contributing to the inability to control EBV infections [24-27]. Patients usually exhibit progressive loss of serum IgG and develop B cell lymphomas and dys-gammaglobulinemia [28-31].

Not until twenty years after the description of XLP, the genetic cause was determined by the Terhorst lab: mutations in or deletion of the $S H 2 D 1 A$ gene, which encodes a $15 \mathrm{kD}$ cytoplasmic protein SAP consisting of a single Src homology 2 (SH2) domain and a 28 
amino acid tail [32-35]. In the same publication, SAP was shown to bind to SLAMF1 and subsequent studies showed binding of SAP to ITSM motifs in the cytoplasmic tail of six of the SLAMF receptors (Figure 3) [1, 30, 34, 35]. SAP was then identified to be required for recruitment and activation of Src-family kinase FynT upon SLAM ligation [36]. Subsequently, the crystal structure of the SLAM-SAP-Fyn-SH3 ternary complex revealed that SAP binds the FynT SH3 domain through a non-canonical surface interaction and couples Fyn to SLAM receptors (Figure 4) [37].

SAP is mainly expressed in T cells, NK cells, NKT cells and eosinophils while expression in B cells is found only in some cases [33, 34, 38-40]. Of note, later research also identified mutations in XIAP, X-linked inhibitor of apoptosis, which are associated with XLP like disease manifestations in a small number of families [41, 42].

Studies from SAP deficient mice shed light on understanding the basis of XLP. Naïve $\mathrm{CD}^{+} \mathrm{T}$ cells from SAP deficient mice exhibited reduced production of peptide-MHC or $\mathrm{T}$ cell receptor (TCR) driven $T_{H} 2$ cytokines [43-46]. In addition, germinal center formation is significantly impaired and antibody secreting cells (ASCs) and memory B cells are lost leading to severely reduced levels of serum $\lg G$ and $\lg E[43,47-49]$. Later, these defects were also identified in XLP patients $[50,51]$.

In SAP deficient mice there appeared to a B cell defect, which was dependent on the genetic background [52] as evidenced by adoptive transfer studies of SAP deficient B cells and WT CD4 ${ }^{+} \mathrm{T}$ cells [47]. Although the B cell defect seems secondary to that of $\mathrm{CD}^{+} \mathrm{T}$ cells $[48,49,51]$, in vitro experiments suggested an intrinsic defect in class switching [40]. 
$\mathrm{CD}^{+} \mathrm{T}$ cells and NK cell functions are also altered in SAP deficient mice and XLP patients. While human in vitro studies suggested SAP is required for induction of cytotoxicity by $\mathrm{CD} 8^{+} \mathrm{T}$ cells [53], SAP deficient mice presented more virus specific $\mathrm{CD} 8^{+}$ T cells in lymphocytic choriomeningitis virus (LCMV) and $\gamma$-herpesvirus 68 infections, suggesting SAP inhibits $\mathrm{CD}^{+} \mathrm{T}$ cell responses $[54,55]$. Finally, SAP was found to be indispensable for NKT cell development as SAP deficient mice and XLP patients lack NKT cells [56-58].

In summary, SAP signaling is critical for mounting proper immune responses. Moreover, SAP, as well as EAT-2, regulates signaling through SLAMFs by setting thresholds for activation/inhibition and modulating cell-cell interactions and responses. Here, we will highlight the roles of SLAMF receptors in regulating normal immune responses and how they are involved in hematological malignancies. 


\section{Immune cell Functions of SLAMF6 (CD352, Ly108, NTB-A)}

SLAMF receptors are adhesion molecules that are involved in development of lymphocytes and in orchestrating innate and adaptive immune responses. While contribution of each SLAMF member is unique, they can have compensating or opposing roles in function. Role of SLAMF6 in immune regulation will be discussed in this section.

\subsection{Structure, expression and ligands}

SLAMF6 (human: NTB-A, mouse: Ly108) structural details are reviewed elsewhere [3]. In mice, different alternatively spliced forms exist: Ly108.1 and Ly108.2 were first identified, containing one and two additional unique tyrosine motifs, respectively $[59,60]$. Later a novel isoform Ly108-H1 was discovered [61]. Tyrosine phosphorylation of the cytoplasmic tail of SLAMF6 leads to recruitment of SAP with high affinity binding, but in the absence of phosphorylation, SAP cannot be recruited $[3,62,63]$. Binding of SAP activates downstream signaling by recruiting the Src family kinase Fyn $[37,64,65]$. This interaction prevents the tyrosine phosphatases SHP1 and/or SHP2 from binding to the cytoplasmic tail and their subsequent negative regulation [34, 35].

SLAMF6 is expressed on a wide variety of immune cells including $T$ cells (also $T_{F H}$ ), $B$ cells, NK cells (expressed in human only), double positive thymocytes, eosinophils and neutrophils (mouse only) [6, 38, 59, 66-69]. Furthermore, high expression of SLAMF6 has been determined in various B cell lymphomas, i.e. mantle cell and follicular 
lymphomas [70]. Expression on normal as well as malignant cells suggests that SLAMF6 may be involved in distinct cell-cell interactions in different microenvironments and may be a useful therapeutic target.

A SLAMF6 homolog, S1, with a 97\% amino acid sequence identity in its ligand binding $\mathrm{N}$-terminal Ig domain have been identified in SMCMV and OMCMV [71]. This was acquired by retrotranscription of virus-host coevolution by the new world monkey CMV. This suggests an immune evasion mechanism of viruses by acquiring the host SLAMF receptors that retain the ligand binding capacity. This allows the interference with host SLAMF functions and induces immunomodulatory actions.

In addition to being a self-ligand, SLAMF6 detects viral and bacterial components as well. For instance, human and mouse SLAMF6 bind the outer membrane proteins OmpC and OmpF, of E.coli, S. typhimurium, and in part to Citrobacter rodentium [18, 21]. Human SLAMF6 can recognize the influenza haemagglutinin $(\mathrm{HA})$ and Vpu protein of HIV-1, both of which affect NK cell cytotoxicity mediated by SLAMF6 $[72,73]$.

\subsection{SLAMF6 signaling in T and B cells}

Co-stimulatory molecules play an important role in activation and initiation of proper T cell responses upon TCR engagement. CD28 is the best-known secondary signal necessary for T cell activation. However, studies from CD28 deficient mice suggested additional co-stimulatory molecules play a role as antigen dependent $\mathrm{T}$ cell responses were still intact in these mice $[74,75]$. In the absence of CD28, stimulation and crosslinking of SLAMF6 with monoclonal antibodies in vitro leads to recruitment of SAP to the phosphorylated cytoplasmic tail, and subsequent events lead to T cell proliferation 
and cytokine production [76]. When SLAMF6 was blocked in vivo using a soluble SLAMF6-Fc fusion protein, B cell isotype switching to $\lg$ G2a and $\lg G 3$ was blocked [76]. In fact, injections of anti-SLAMF6 to WT mice immunized with NP-OVA or in a chronic graft versus host disease (cGVHD) model inhibited $T$ and $B$ cell responses in these distinct in vivo models [77-79].

Involvement of SLAMF6 in regulating immune responses was demonstrated using mice deficient in SLAMF6 [80]. Expression of the SLAMF6 extracellular domain was disturbed by removal of exons 2 and 3 (Ly108 $\Delta \mathrm{E} 2+3)$ [80]. In vivo infection of Ly108 $\Delta \mathrm{E} 2+3$ mice with L. mexicana led to delayed formation of lesions as well as significantly smaller lesions compared to WT controls, indicating a role for Ly108 in innate and adaptive immune responses.

Under normal circumstances, $\mathrm{T}$ cell expansion upon infections is constrained by a mechanism called restimulation-induced cell death (RICD), which induces apoptosis of effector T cells during the peak of an immune response [81]. Upon restimulation of these T cells, pro-apoptotic molecules are upregulated, such as FAS ligand and BIM, to induce apoptosis. This mechanism was found to be defective in patients with XLP, mainly due to absence of SAP and defective signaling through SLAMF6 [82]. In RICD, SAP/SLAMF6 signaling was shown to augment TCR signaling to achieve the threshold necessary for RICD. This was facilitated by SAP's recruitment of Lck, but not Fyn, to the cytoplasmic tail [83].

SLAMF6 is also implicated in trogocytosis, the transfer of membrane patches from target to effector $\mathrm{T}$ cells $[84,85]$. The trogocytosis capacity of $\mathrm{CD}^{+} \mathrm{T}$ cell clones from melanoma patients correlated with their cytotoxic capacity. Furthermore, higher cytotoxic capacity was correlated with increased phosphorylation of SLAMF6 [84]. Enhanced 
cytotoxicity of these $\mathrm{CD}^{+} \mathrm{T}$ cells could be blocked by an antagonist $\alpha$ SLAMF6, indicating that SLAMF6 co-stimulation plays an active role in T cell functional diversity. As $C D 8^{+} \mathrm{T}$ cells from XLP patients are defective in cytolytic activity against EBV-infected B cell targets, SLAMF6 as well as SAP may be involved [53, 86-88]. Mice deficient in SAP presented altered T cell responses including short-lived T-B cell interactions, defective germinal center formation, and humoral immunity $[2,63,89]$. As $\mathrm{CD}^{+} \mathrm{T}$ cells are critical in controlling infections, the role of SAP as well as contributions of SLAMFs were investigated. Studies using SAP deficient mouse T cells showed inefficient killing of B cell target cells, but not others, suggesting SAP is especially critical in T-B cell interactions [90]. These defects were at the level of immune synapse organization and inefficient actin clearance. Conjugation of OVA-pulsed B cells with WT or SAP-/cytotoxic $\mathrm{CD}^{+} \mathrm{T}$ lymphocytes (CTL) showed significant SHP-1 localization at the immune synapse with SAP-/- CTL compared to WT CTL as quantified from immunofluorescence microscopy images [90]. This suggested that in the absence of SAP, SHP1 is recruited to the cytoplasmic tail of SLAMF6 [79]. When B cell targets were SLAMF6 deficient, killing ability of SAP-/- T cells was rescued demonstrating that SLAMF6 is an important regulator of SAP dependent responses from CTLs. Our current understanding of how SLAMF6 may play a role in T-B cell interactions is summarized in Figure 5.

\subsection{SLAMF6 controls neutrophil functions}

Disruption of Ly108 expression in mice (Ly108 $\Delta \mathrm{E} 2+3)$ also revealed a role for Ly108 in neutrophil functions [80]. In response to infections with Salmonella typhimurium, neutrophils exhibited significantly reduced reactive oxygen species (ROS) production 
and bacterial killing with increased IL-6, IL-12 and TNF- $\alpha$ production compared to WT controls. Mechanisms of Ly108 signaling involved in ROS production is still not known. While neutrophils are not implicated in XLP and human neutrophils do not appear to express SLAMF6, it may be of interest to investigate whether the expression can be induced upon activation.

\subsection{SLAMF6 is an activating receptor on human NK cells}

Activating signals induced upon ligation of NTB-A on an NK cell induces phosphorylation of its cytoplasmic tail, which is Src kinase dependent, and leads to recruitment of SAP, EAT-2 and SHP1/2 [91, 92]. Full SLAMF6 dependent activation of NK cell cytotoxicity depends on simultaneous binding of SAP and EAT-2 to the phosphorylated tyrosine residues on the cytoplasmic tail [92]. Crosslinking of human SLAMF6 with antibodies stimulate NK cells for target cell killing in cytotoxicity assays, and homophilic interaction of ligands induces NK cell cytotoxicity against target cells with subsequent IFN $\gamma$ and TNF $\alpha$ secretion $[66,91]$. However, if the SLAMF6 homophilic interaction between an NK cell and a target cell is blocked using an anti-SLAMF6 antibody, NK cell cytotoxicity is inhibited [69]. Interestingly, blocking the homophilic interaction between neighboring NK cells has no effect on proliferation or cytotoxicity [93]. Instead, homophilic interaction with a MHC-I negative target cell induces potent cytotoxicity of NK cells. This selective mechanism is probably in place to ensure NK cells do not end up killing each other.

While expression of SLAMF receptors is restricted to hematopoietic cells, a recent study demonstrated that SLAMF6 enhanced activation of NK cells against a nonhematopoietic target cell [94]. This was regulated by SAP, which uncoupled SHP-1 binding from the cytoplasmic tail of SLAMF6, diminishing the effect of the receptor on NK 
cell responsiveness to non-hematopoietic cells. This proved that SLAM-SAP pathways could also influence NK cell education [94].

\subsection{SLAMF6 regulates NKT cell development}

Natural killer T (NKT) cells represent a subset of $T$ lymphocytes that develop from double positive (DP) $C D 4^{+} \mathrm{CD}^{+}$precursor cells in the thymus [95]. While positive selection of conventional T cells is mediated by interactions with thymic epithelial cells, NKT cells are selected by lipid antigens presented by CD1d on other DP thymocytes [96, 97]. These cells express an invariant TCR and can rapidly secrete cytokines following infections [98].

With the severe lack of NKT cells in XLP patients, SAP was hypothesized to be involved in NKT cell development [1]. Indeed, mouse studies showed that SAP expression in NKT cells is necessary for cognate help to B cells[99]. As binding of SAP and recruitment of Fyn is induced by signaling through SLAMF receptors, SLAMF1 and SLAMF6, which are expressed on DP thymocytes, their possible role in NKT cell development was investigated. Mouse studies from single knockouts $\left(\mathrm{SLAMF}^{-{ }^{-}}{ }^{-} \mathrm{SLAMF}^{-1}\right.$ ) revealed only a modest effect on NKT cell development, probably due to overlapping functions of these two receptors $[80,100]$. Supporting this hypothesis, mice reconstituted with double mutant $\left(\mathrm{SLAMF}^{-1-} \mathrm{SLAMF6}^{-1}\right)$ bone marrow chimeras had severely impaired NKT cell development [68]. Furthermore, expression of promyelocytic zinc finger (PLZF), a transcription factor required for development of invariant NKT (iNKT) and other innate like $\mathrm{T}$ lymphocytes, was demonstrated to be modulated by co-stimulation through 
SLAMF6 [101-103]. These studies together underline the importance of SLAMF6 in NKT cell development. Other SLAMF members were also found to regulate NKT cell development in a SAP dependent and independent manner [104].

It has also been determined that SLAMF6 acts as a SAP-dependent on and off switch for stable T-B cell interactions [79]. In the absence of SAP, SLAMF6 recruited the negative regulator SHP-1 at the T-B cell synapse limiting adhesion. Interestingly, when both SAP and SLAMF6 were removed $\left(\mathrm{SAP}^{-/-} \mathrm{SAMF}^{-/}\right)$, both $\mathrm{CD} 4^{+} \mathrm{T}$ cell function as well as NKT cell differentiation was restored. Therefore, SLAMF6 also serves an important role in sending positive and negative signals depending on the competition between SAP and SHP-1 binding, which in turn regulates T cell help and NKT cell development.

\subsection{SLAMF6 as a susceptibility gene for Systemic Lupus}

\section{Erythematosus}

Systemic lupus erythematosus (SLE) is a chronic autoimmune disease that mainly affects females and is characterized by the production of autoantibodies against self antigens [105]. Generation of these antibodies results in clinical manifestations including arthritis, kidney damage, skin disease and blood cell abnormalities. Both genetic and environmental factors are known to contribute to disease manifestation $[105,106]$.

Analysis of the SLAM/CD2 gene cluster revealed extensive polymorphisms, and among 35 inbred mouse strains two stable haplotypes were identified [60, 107]. Haplotype 1 is found in C57BL/6J (B6) and related strains while haplotype 2 is found in autoimmuneprone mouse strains, i.e. NZW[60]. It appeared that autoimmunity was induced only when the haplotype 2 SLAM locus was expressed in B6 background [60]. Sle1 was 
identified on murine chromosome 1 as a cause of loss of tolerance and autoantibody production. Fine mapping of the Sle1 locus identified 4 loci contributing to the disease manifestation, one of which was the most potent: Sle1b [60]. The congenic B6.Sle1b mouse strain presented with spontaneous autoimmunity and production of antinuclear antibodies (ANAs), indicating a failure to maintain central and peripheral tolerance [60, 108, 109]. Among the SLAMF genes, SLAMF6 was the strongest candidate for lupus due to the expression of alternatively spliced variants: Ly108-1 and Ly108-2. Of the two, Ly108-1 had a greater tendency to be phosphorylated at the cytoplasmic tail for SAP, Fyn recruitment and signaling than Ly108-2 isoform [110]. Kumar et al. and colleagues demonstrated that the Ly108-1 isoform was more abundant in B6.Sle1b mice compared to B6 mice, which was found to sensitize immature B cells to deletion and RAG reexpression [111]. This study provided the idea that SLAMF6 serves as a regulatory checkpoint for self-reactive B cells to protect from autoimmunity.

A later study identified a new isoform of Ly108 present in haplotype 1 but not haplotype 2: Ly108-H1 [61]. This isoform was found to regulate SLE in a CD4 ${ }^{+} \mathrm{T}$ cell dependent manner and expression of this isoform in lupus-prone mice significantly suppressed autoimmunity. Deletion of SLAMF6 in Chr1b also disrupted the autoimmune phenotype. In addition, autoimmunity in B6.Sle1b mice correlated with expansion of an osteopontinexpressing TFH cell subset, which was suppressed when the Ly108-H1 isoform was expressed in these mice [112]. Overall, these studies pointed to the importance of alternative splicing in pathogenesis of SLE and that both B and T cell tolerance is compromised. 


\section{SLAMF6 in Hematological Malignancies}

Hematologic malignancies are cancers that affect the blood, lymphatic system and the bone marrow. Malignant cells arise from blood cells of common lymphoid and myeloid progenitor origin and are categorized under three main subsets: leukemias (acute and chronic), lymphomas and myelomas [113]. Chromosomal translocations are a common cause of these diseases unlike solid tumors, and thus are commonly used as diagnostic factors.

As SLAMF members are expressed on a variety of normal immune cells that form the tumor microenvironment as well as cells that become malignant, it is plausible to hypothesize that SLAMFs may play a role in all these complex interactions. In fact, in recent years many investigators have demonstrated relevant roles for SLAMFs, SLAMF6 in chronic lymphocytic leukemia and SLAMF7 in multiple myeloma (MM), of which SLAMF6 will be discussed in further detail.

\subsection{The Pathogenesis of Chronic Lymphocytic Leukemia}

Chronic lymphocytic leukemia (CLL) is the most common leukemia in western countries accounting for $40 \%$ of all leukemias. It is a malignancy of mature $\mathrm{CD}^{+} \mathrm{B}$ cells that accumulate in the blood, bone marrow and secondary lymphoid organs [114]. Phenotypically they are similar to antigen-experienced B cells expressing CD19, CD5, CD23, CD25, CD69 and CD71, and the memory B cell marker CD27 [115-117]. CLL is broadly divided into 2 subsets depending on the immunoglobulin (Ig) heavy chain mutation status (IGHV). CLL B cells with unmutated IGHV (U-CLL) derive from mature 
$\mathrm{CD5}^{+} \mathrm{B}$ cells, whereas CLL cells with mutated IGHV (M-CLL) derive from $\mathrm{CD} 5^{+} \mathrm{CD} 27^{+}$ post-germinal center B cell subsets [118].

CLL patients can have varying clinical outcomes depending on the aggressiveness of the disease. While some patients are stable and are only observed over time without any need for treatment, some experience more aggressive disease and require immediate treatment. Multiple factors play role in determining the course of the disease. Mutational status of CLL B cells is an important prognostic factor and patients with U-CLL show a more aggressive disease and shorter survival time compared to M-CLL patients [119, 120]. Chromosomal alterations are another parameter for disease outcome. Patients with $13 q$ deletions that include the miRNAs miR15a and miR16-1 are usually associated with favorable disease outcome [121]. Mouse models with deletion of the miR15a and miR16-1 locus mimic many features of human CLL [122]. Chromosomal deletion of $17 p$ and $11 \mathrm{q}$ harbor the p53 and ataxia telangiectasia mutated (ATM) genes and are associated with poor disease outcome $[121,123]$. Trisomy 12 is found in 15\% of CLL patients and signifies an intermediate prognosis. In addition to chromosomal aberrations, high expression of CD38 and ZAP70 in CLL B cells is associated with a poor outcome and shorter time to treatment $[119,124,125]$. Besides these clinical markers that are associated with disease outcome of CLL patient, studies using the application of whole exome sequencing have identified recurrent somatic mutations that are involved in DNA damage, mRNA processing, WNT and Notch signaling and chromatin modifications that can affect B cell signal transductions [126-129].

\subsubsection{CLL Microenvironment}

Cells of the immune system coevolve with the tumor and provide the tumor a friendly microenvironment for survival of CLL cells. Culturing CLL B cells in vitro after isolation 
from peripheral blood mononuclear cells (PBMCs) leads to the induction of spontaneous apoptosis indicating that CLL B cells are highly dependent on the microenvironment for survival signals $[130,131]$. Only when cultured with bone marrow stromal cells, CLL B cells survived in vitro. This suggests that the tumor microenvironment in vivo has a profound effect on survival and expansion of CLL leukemic cells [114]. Some of the key interactions between CLL B cells and the tumor microenvironment are highlighted in

\section{Figure 6.}

One of the CLL supporting cells is the 'nurse like cells' (NLCs), which are of monocyte origin [132]. These cells were found to differentiate in vitro from PBMCs of CLL patients and secrete chemokines such as CXCL12 and CXCL13 for their survival in vitro [132, 133]. These chemokines induce chemotaxis for migration of CLL cells in and out of secondary lymphoid organs in vivo. CXCL12 mediated signaling is increased by CD38 expressed on CLL cells further promoting survival $[134,135]$. NLCs also activate the B cell receptor signaling and NF-kB pathway for survival [136].

The B cell receptor (BCR) signaling pathway is a key survival factor for CLL [137]. The $\mathrm{BCR}$ is composed of an antigen-specific surface membrane $\lg (\mathrm{smlg})$ along with $\lg \alpha / \lg \beta$ heterodimers. Engagement of the BCR triggers phosphorylation of $\lg \alpha / \lg \beta$ and recruitment of Lyn, which in turn activates kinases SYK, BTK and PI3K. This leads to the activation of downstream signaling cascades including phospholipase C gamma 2 (PLC $\gamma 2$ ), calcium signaling, NF-kB and mitogen-activated protein kinase (MAPK) pathways. These signaling events promote survival and proliferation of B cells [138]. IGHV mutation status of CLL cells determines the responsiveness of BCR engagement. While CLL B cells from U-CLL patients are more responsive to BCR stimulation and mostly recognize autoantigens $[139,140]$, M-CLL cells show constitutive phosphorylation of ERK kinase along with reduced surface BCR leading to an "anergic" 
phenotype [141, 142]. In addition to activated BCR signaling, ligation of CD40/CD40L on malignant B cells and T cells also promote survival of CLL cells [143].

Another hallmark of CLL is dysfunctional $\mathrm{T}$ cells in the tumor microenvironment. Although there is an overall expansion in the T cell compartment, the normal CD4/CD8 ratio appears to be inverted due to differential sensitivity of $\mathrm{CD}^{+}$and $\mathrm{CD}^{+} \mathrm{T}$ cells to Fas/Fas Ligand induced cell death [144-148]. Within CD4 $T$ cells, frequency of regulatory $T$ cells (Treg) is increased further supporting leukemic expansion [149-151]. $\mathrm{CD}^{+}$and $\mathrm{CD}^{+} \mathrm{T}$ cells show many defects in CLL including $\mathrm{T}$ cell exhaustion, inability to form immune synapses and impaired cytotoxic function [152-154]. Exhausted CD8 T cell state correlates with increased expression of exhaustion markers such as programmed death-1 (PD-1), CD160, SLAMF4 and KLRG1[152, 155-157]. Several studies hypothesized one factor for exhaustion may be cytomegalovirus (CMV) infection that influences and expands the CMV-specific $\mathrm{CD}^{+}$and $\mathrm{CD}^{+} \mathrm{T}$ cell subsets in healthy individuals and is also expanded in CMV-seropositive CLL patients [158-160]. However, within the exhausted T cell pool, CMV-specific T cells showed reduced expression of exhaustion markers as well as retained cytotoxic capacity and cytokine production compared to other exhausted $\mathrm{T}$ cells $[161,162]$. These data indicated that there might be other factors influencing changes in the T cell compartment in CLL.

PD-1/PD-L1 is a major pathway contributing to the known T cell defects in CLL [163]. PD-L1 is overexpressed on CLL cells and myeloid derived suppressor cells (MDSCs), which further up-regulates PD-1 on T cells $[164,165]$. Within CD4 and CD8 T cell populations, naïve $\mathrm{T}$ cells are reduced while effector memory $\mathrm{CD}^{+} \mathrm{T}$ cells and terminally differentiated $\mathrm{CD}^{+} \mathrm{T}$ cells are increased, which clinically corresponds with disease aggressiveness [163]. Up-regulated PD-1 inhibits IFN $\gamma$ secretion skewing the 
immune responses to a dysregulated $\mathrm{T}_{\mathrm{H}} 2$ response [163]. These $\mathrm{T}$ cell defects are recapitulated in the TCL1 transgenic ( $\mathrm{E} \mu-\mathrm{TCL} 1)$ mouse model of CLL [166-168], allowing a useful platform to study and understand the contribution of PD1/PD-L1 pathway in CLL pathogenesis and how this pathway can be targeted therapeutically.

\subsubsection{Therapeutic options in CLL}

Allogeneic hematopoietic stem cell transplantation (HSCT) represents one of the oldest treatments for hematological malignancies which set the foundation for the development of cancer immunotherapy [169]. Performed for the first time in 1968, high doses of radiation and chemotherapy were given to the patient that wiped out the entire immune system followed by donor HSC transplantation for repopulation of the hematopoietic system. Extensive studies over the years provided great insight into the efficiency of the ability of donor immune cells to eliminate recipient tumor cells. This is known as "graft versus leukemia' (GVL) effect. GVL potency was further appreciated by the finding that post- HSCT, donor lymphocyte infusions (DLI) induced remarkable responses and remissions without radiation or chemotherapy, in leukemias [170, 171].

Targeting BCR signaling using small inhibitor molecules has dramatically improved treatment options for CLL patients [137]. The BTK inhibitor, ibrutinib (PCl-32765) binds irreversibly to a cysteine residue (Cys-481) in the BTK kinase domain and inhibits its phosphorylation and enzymatic activity [172]. Ibrutinib inhibited proliferation and stromal cell contact of CLL cells and reduced their viability in vitro [173]. Ibrutinib also prevented tissue homing in response to chemokines CXCL12 and CXCL13 in vitro and in a mouse model of CLL [174]. This inhibition of tissue homing chemokines directly correlated with 
a transient lymphocytosis in CLL patients undergoing ibrutinib treatment, which allowed CLL cells to move from secondary lymphoid organs into the circulation and induced cell death [175]. Because ibrutinib not only binds to BTK in CLL B cells but also to ITK in T cells, its immunomodulatory role was also investigated in CLL patients [176]. In patients treated with ibrutinib, the increased $\mathrm{T}$ cell numbers normalized and production of inflammatory cytokines were reduced, and the T cell repertoire diversity increased [177, 178]. Ibrutinib also reduced Treg numbers [179]. Expression of PD-1 and PD-L1 upon ibrutinib treatment markedly decreased, improving activated effector $\mathrm{T}$ cell functions $[180,181]$

While ibrutinib targeted CLL B and T cells, a second-generation highly selective BTK inhibitor, acalabrutinib, was produced [182]. Pharmacodynamics and proteomic analysis appeared to be similar on leukemic cells compared to ibrutinib, while off target effects on T cells was more pronounced using ibrutinib than acalabrutinib [183, 184].

Rituximab, a monoclonal antibody against the B cell surface antigen CD20, is widely used in the treatment of B cell malignancies including CLL [185-187]. The primary mode of action of rituximab includes ADCC and complement dependent cytotoxicity (CDC) as well as direct anti-proliferative and pro-apoptotic effects [188, 189]. While major advances were brought by rituximab, relapse and resistance to treatment are eventually seen in patients. One potential reason is the removal of bound CD20 complexes from the surface of CLL cells by trogocytosis $[190,191]$. Administering rituximab together with ibrutinib led to better responses, but follow up studies identified that ibrutinib interferes with the effect of rituximab by downregulating CD20 on the cell surface of CLL cells [192, 193]. More efficient combinations with rituximab may be required for better and durable effects of this immunotherapy agent. 
Lenalidomide is an immunomodulatory agent that affects the tumor microenvironment and the immune system. In particular, it corrects CLL B cell - T cell immunological synapse formation and down-regulates PD-1 on T cells $[153,164,194]$. Lenalidomide normalizes total T cell and Treg numbers, similar to ibrutinib, in vivo [195]. Combining lenalidomide with $\alpha \mathrm{CD} 20$ improved ADCC activity of NK cells in vitro, and this combination also demonstrated efficacy in clinical trials [196, 197]. Other small inhibitor molecules targeting BCR signaling, monoclonal antibodies and immunomodulatory drugs used in treatment of CLL patients are discussed in detail elsewhere [137, 198].

\subsection{SLAMF Receptors in CLL}

The importance of SLAMF receptors in regulating innate and adaptive immune responses makes them relevant candidates in context of various diseases including chronic lymphocytic leukemia. SLAMF receptors, particularly SLAMF6 is expressed on both human and mouse CLL cells [199].

SLAMF6 expression is high on normal T and B cells and studies have already indicated its importance in B-T cell signaling. Therefore it was plausible to hypothesize that monoclonal antibodies targeting SLAMF6 may be of therapeutic interest in CLL [199]. An adoptive transfer model of an aggressive TCL1 clone, TCL1-192 [200], into SCID (severe combined immune deficiency) mice, which lack $T$ and $B$ cells, was injected with anti-SLAMF6 upon leukemic. This led to significantly reduced leukemic burden by inducing antibody dependent cellular cytotoxicity $(A D C C)$ and reduced proximal $B$ cell receptor signaling [199]. Interestingly, the antibody was unable induce ADCC in 
peritoneal cavity (PerC) of mice, due to possibly different microenvironments and signaling compared to blood or spleen $[199,201]$. One such finding was the elevated reactive oxygen species (ROS) production in PerC CLL B and normal B1a B cells compared to the cells residing in spleen [201]. While inhibition of ROS limited leukemic expansion in this niche, the finding that ROS is reduced upon BTK inhibitor, ibrutinib and leukemic infiltration to the blood, prompted us to do a combination therapy. By combining anti-SLAMF6 with ibrutinib, leukemic cells were pushed out of this niche into the circulation making them targetable by the antibody. This led to an overall greater reduction in leukemic burden than either regimen alone. Exploration of SLAMF6 as a therapeutic target would be of great interest in CLL and other B cell malignancies. 


\section{Conclusions}

SLAMF6 receptor plays vital roles in maintaining a balanced immune response and its interrupted functions are associated with various diseases. Ability of SLAMF6 receptors, as well as other SLAMFs, to play activating and inhibitory roles depending on the signals they receive or the cell-cell interactions they encounter makes them an important target when thinking about designing therapeutics. Monoclonal antibodies that can block or engage SLAMF6-SLAMF6 interactions are being targeted in diseases such as CLL. Further understanding the fundamentals on how SLAMF6 plays a role in the bigger picture will make them once step closer to being targets in many more diseases. 


\section{References}

[1] P. Engel, M.J. Eck, C. Terhorst, The SAP and SLAM families in immune responses and X-linked lymphoproliferative disease, Nature reviews. Immunology, 3 (2003) 813-821.

[2] C. Detre, M. Keszei, X. Romero, G.C. Tsokos, C. Terhorst, SLAM family receptors and the SLAM-associated protein (SAP) modulate $\mathrm{T}$ cell functions, Seminars in immunopathology, 32 (2010) 157-171.

[3] S. Calpe, N. Wang, X. Romero, S.B. Berger, A. Lanyi, P. Engel, C. Terhorst, The SLAM and SAP gene families control innate and adaptive immune responses, Advances in immunology, 97 (2008) 177-250.

[4] C.S. Ma, E.K. Deenick, The role of SAP and SLAM family molecules in the humoral immune response, Annals of the New York Academy of Sciences, 1217 (2011) 32-44. [5] N. Wang, M. Morra, C. Wu, C. Gullo, D. Howie, T. Coyle, P. Engel, C. Terhorst, CD150 is a member of a family of genes that encode glycoproteins on the surface of hematopoietic cells, Immunogenetics, 53 (2001) 382-394.

[6] C.C. Fraser, D. Howie, M. Morra, Y. Qiu, C. Murphy, Q. Shen, J.C. Gutierrez-Ramos, A. Coyle, G.A. Kingsbury, C. Terhorst, Identification and characterization of SF2000 and SF2001, two new members of the immune receptor SLAM/CD2 family, Immunogenetics, 53 (2002) 843-850.

[7] V. Tovar, J. del Valle, N. Zapater, M. Martin, X. Romero, P. Pizcueta, J. Bosch, C. Terhorst, P. Engel, Mouse novel Ly9: a new member of the expanding CD150 (SLAM) family of leukocyte cell-surface receptors, Immunogenetics, 54 (2002) 394-402. 
[8] S. Yokoyama, D. Staunton, R. Fisher, M. Amiot, J.J. Fortin, D.A. Thorley-Lawson, Expression of the Blast-1 activation/adhesion molecule and its identification as CD48, Journal of immunology, 146 (1991) 2192-2200.

[9] C. Wu, J. Sayos, N. Wang, D. Howie, A. Coyle, C. Terhorst, Genomic organization and characterization of mouse SAP, the gene that is altered in X-linked lymphoproliferative disease, Immunogenetics, 51 (2000) 805-815.

[10] Y. Latchman, P.F. McKay, H. Reiser, Identification of the 2B4 molecule as a counter-receptor for CD48, Journal of immunology, 161 (1998) 5809-5812.

[11] M.H. Brown, K. Boles, P.A. van der Merwe, V. Kumar, P.A. Mathew, A.N. Barclay, 2B4, the natural killer and $\mathrm{T}$ cell immunoglobulin superfamily surface protein, is a ligand for CD48, The Journal of experimental medicine, 188 (1998) 2083-2090.

[12] C.A. Velikovsky, L. Deng, L.K. Chlewicki, M.M. Fernandez, V. Kumar, R.A. Mariuzza, Structure of natural killer receptor 2B4 bound to CD48 reveals basis for heterophilic recognition in signaling lymphocyte activation molecule family, Immunity, 27 (2007) 572-584.

[13] Q. Yan, V.N. Malashkevich, A. Fedorov, E. Fedorov, E. Cao, J.W. Lary, J.L. Cole, S.G. Nathenson, S.C. Almo, Structure of CD84 provides insight into SLAM family function, Proceedings of the National Academy of Sciences of the United States of America, 104 (2007) 10583-10588.

[14] E. Cao, U.A. Ramagopal, A. Fedorov, E. Fedorov, Q. Yan, J.W. Lary, J.L. Cole, S.G. Nathenson, S.C. Almo, NTB-A receptor crystal structure: insights into homophilic interactions in the signaling lymphocytic activation molecule receptor family, Immunity, 25 (2006) 559-570. 
[15] N. Mavaddat, D.W. Mason, P.D. Atkinson, E.J. Evans, R.J. Gilbert, D.I. Stuart, J.A. Fennelly, A.N. Barclay, S.J. Davis, M.H. Brown, Signaling lymphocytic activation molecule (CDw150) is homophilic but self-associates with very low affinity, The Journal of biological chemistry, 275 (2000) 28100-28109.

[16] H. Tatsuo, N. Ono, K. Tanaka, Y. Yanagi, SLAM (CDw150) is a cellular receptor for measles virus, Nature, 406 (2000) 893-897.

[17] T. Hashiguchi, T. Ose, M. Kubota, N. Maita, J. Kamishikiryo, K. Maenaka, Y. Yanagi, Structure of the measles virus hemagglutinin bound to its cellular receptor SLAM, Nature structural \& molecular biology, 18 (2011) 135-141.

[18] S.B. Berger, X. Romero, C. Ma, G. Wang, W.A. Faubion, G. Liao, E. Compeer, M. Keszei, L. Rameh, N. Wang, M. Boes, J.R. Regueiro, H.C. Reinecker, C. Terhorst, SLAM is a microbial sensor that regulates bacterial phagosome functions in macrophages, Nature immunology, 11 (2010) 920-927.

[19] D.M. Baorto, Z. Gao, R. Malaviya, M.L. Dustin, A. van der Merwe, D.M. Lublin, S.N. Abraham, Survival of FimH-expressing enterobacteria in macrophages relies on glycolipid traffic, Nature, 389 (1997) 636-639.

[20] C. Ma, N. Wang, C. Detre, G. Wang, M. O'Keeffe, C. Terhorst, Receptor signaling lymphocyte-activation molecule family 1 (Slamf1) regulates membrane fusion and NADPH oxidase 2 (NOX2) activity by recruiting a Beclin-1/Vps34/ultraviolet radiation resistance-associated gene (UVRAG) complex, The Journal of biological chemistry, 287 (2012) 18359-18365.

[21] B. van Driel, G. Wang, G. Liao, P.J. Halibozek, M. Keszei, M.S. O'Keeffe, A.K. Bhan, N. Wang, C. Terhorst, The cell surface receptor Slamf6 modulates innate immune 
responses during Citrobacter rodentium-induced colitis, International immunology, 27 (2015) 447-457.

[22] B.J. van Driel, G. Liao, P. Engel, C. Terhorst, Responses to Microbial Challenges by SLAMF Receptors, Front Immunol, 7 (2016) 4.

[23] D.T. Purtilo, C.K. Cassel, J.P. Yang, R. Harper, X-linked recessive progressive combined variable immunodeficiency (Duncan's disease), Lancet, 1 (1975) 935-940. [24] J.L. Sullivan, K.S. Byron, F.E. Brewster, D.T. Purtilo, Deficient natural killer cell activity in x-linked lymphoproliferative syndrome, Science, 210 (1980) 543-545.

[25] S. Harada, T. Bechtold, J.K. Seeley, D.T. Purtilo, Cell-mediated immunity to Epstein-Barr virus (EBV) and natural killer (NK)-cell activity in the X-linked lymphoproliferative syndrome, International journal of cancer, 30 (1982) 739-744.

[26] S. Argov, D.R. Johnson, M. Collins, H.S. Koren, H. Lipscomb, D.T. Purtilo, Defective natural killing activity but retention of lymphocyte-mediated antibodydependent cellular cytotoxicity in patients with the X-linked lymphoproliferative syndrome, Cellular immunology, 100 (1986) 1-9.

[27] F. Rousset, G. Souillet, M.G. Roncarolo, J.P. Lamelin, Studies of EBV-lymphoid cell interactions in two patients with the X-linked lymphoproliferative syndrome: normal EBV-specific HLA-restricted cytotoxicity, Clinical and experimental immunology, 63 (1986) 280-289.

[28] D.S. Harrington, D.D. Weisenburger, D.T. Purtilo, Malignant lymphoma in the Xlinked lymphoproliferative syndrome, Cancer, 59 (1987) 1419-1429. 
[29] R.M. Egeler, J. de Kraker, R. Slater, D.T. Purtilo, Documentation of Burkitt lymphoma with $\mathrm{t}(8 ; 14)(\mathrm{q} 24 ; \mathrm{q} 32)$ in X-linked lymphoproliferative disease, Cancer, 70 (1992) 683-687.

[30] M. Morra, D. Howie, M.S. Grande, J. Sayos, N. Wang, C. Wu, P. Engel, C. Terhorst, X-linked lymphoproliferative disease: a progressive immunodeficiency, Annual review of immunology, 19 (2001) 657-682.

[31] J. Sumegi, D. Huang, A. Lanyi, J.D. Davis, T.A. Seemayer, A. Maeda, G. Klein, M. Seri, H. Wakiguchi, D.T. Purtilo, T.G. Gross, Correlation of mutations of the SH2D1A gene and epstein-barr virus infection with clinical phenotype and outcome in Xlinked lymphoproliferative disease, Blood, 96 (2000) 3118-3125.

[32] A.J. Coffey, R.A. Brooksbank, O. Brandau, T. Oohashi, G.R. Howell, J.M. Bye, A.P. Cahn, J. Durham, P. Heath, P. Wray, R. Pavitt, J. Wilkinson, M. Leversha, E. Huckle, C.J. Shaw-Smith, A. Dunham, S. Rhodes, V. Schuster, G. Porta, L. Yin, P. Serafini, B. Sylla, M. Zollo, B. Franco, A. Bolino, M. Seri, A. Lanyi, J.R. Davis, D. Webster, A. Harris, G. Lenoir, G. de St Basile, A. Jones, B.H. Behloradsky, H. Achatz, J. Murken, R. Fassler, J. Sumegi, G. Romeo, M. Vaudin, M.T. Ross, A. Meindl, D.R. Bentley, Host response to EBV infection in X-linked lymphoproliferative disease results from mutations in an SH2-domain encoding gene, Nature genetics, 20 (1998) 129-135.

[33] K.E. Nichols, D.P. Harkin, S. Levitz, M. Krainer, K.A. Kolquist, C. Genovese, A. Bernard, M. Ferguson, L. Zuo, E. Snyder, A.J. Buckler, C. Wise, J. Ashley, M. Lovett, M.B. Valentine, A.T. Look, W. Gerald, D.E. Housman, D.A. Haber, Inactivating mutations in an SH2 domain-encoding gene in X-linked lymphoproliferative 
syndrome, Proceedings of the National Academy of Sciences of the United States of America, 95 (1998) 13765-13770.

[34] J. Sayos, C. Wu, M. Morra, N. Wang, X. Zhang, D. Allen, S. van Schaik, L. Notarangelo, R. Geha, M.G. Roncarolo, H. Oettgen, J.E. De Vries, G. Aversa, C. Terhorst, The X-linked lymphoproliferative-disease gene product SAP regulates signals induced through the co-receptor SLAM, Nature, 395 (1998) 462-469.

[35] F. Poy, M.B. Yaffe, J. Sayos, K. Saxena, M. Morra, J. Sumegi, L.C. Cantley, C. Terhorst, M.J. Eck, Crystal structures of the XLP protein SAP reveal a class of SH2 domains with extended, phosphotyrosine-independent sequence recognition, Molecular cell, 4 (1999) 555-561.

[36] S. Latour, G. Gish, C.D. Helgason, R.K. Humphries, T. Pawson, A. Veillette, Regulation of SLAM-mediated signal transduction by SAP, the X-linked lymphoproliferative gene product, Nature immunology, 2 (2001) 681-690.

[37] B. Chan, A. Lanyi, H.K. Song, J. Griesbach, M. Simarro-Grande, F. Poy, D. Howie, J. Sumegi, C. Terhorst, M.J. Eck, SAP couples Fyn to SLAM immune receptors, Nature cell biology, 5 (2003) 155-160.

[38] A. Munitz, I. Bachelet, S. Fraenkel, G. Katz, O. Mandelboim, H.U. Simon, L. Moretta, M. Colonna, F. Levi-Schaffer, 2B4 (CD244) is expressed and functional on human eosinophils, Journal of immunology, 174 (2005) 110-118.

[39] L.L. Kis, N. Nagy, G. Klein, E. Klein, Expression of SH2D1A in five classical Hodgkin's disease-derived cell lines, International journal of cancer, 104 (2003) 658-661. 
[40] U. Al-Alem, C. Li, N. Forey, F. Relouzat, M.C. Fondaneche, S.V. Tavtigian, Z.Q. Wang, S. Latour, L. Yin, Impaired Ig class switch in mice deficient for the X-linked lymphoproliferative disease gene Sap, Blood, 106 (2005) 2069-2075.

[41] S. Rigaud, M.C. Fondaneche, N. Lambert, B. Pasquier, V. Mateo, P. Soulas, L. Galicier, F. Le Deist, F. Rieux-Laucat, P. Revy, A. Fischer, G. de Saint Basile, S. Latour, XIAP deficiency in humans causes an X-linked lymphoproliferative syndrome, Nature, 444 (2006) 110-114.

[42] R.A. Marsh, J. Villanueva, K. Zhang, A.L. Snow, H.C. Su, L. Madden, R. Mody, B. Kitchen, D. Marmer, M.B. Jordan, K.A. Risma, A.H. Filipovich, J.J. Bleesing, A rapid flow cytometric screening test for X-linked lymphoproliferative disease due to XIAP deficiency, Cytometry. Part B, Clinical cytometry, 76 (2009) 334-344.

[43] C. Wu, K.B. Nguyen, G.C. Pien, N. Wang, C. Gullo, D. Howie, M.R. Sosa, M.J. Edwards, P. Borrow, A.R. Satoskar, A.H. Sharpe, C.A. Biron, C. Terhorst, SAP controls $\mathrm{T}$ cell responses to virus and terminal differentiation of $\mathrm{TH} 2$ cells, Nature immunology, 2 (2001) 410-414.

[44] D. Davidson, X. Shi, S. Zhang, H. Wang, M. Nemer, N. Ono, S. Ohno, Y. Yanagi, A. Veillette, Genetic evidence linking SAP, the X-linked lymphoproliferative gene product, to Src-related kinase FynT in $\mathrm{T}(\mathrm{H}) 2$ cytokine regulation, Immunity, 21 (2004) 707-717.

[45] M.J. Czar, E.N. Kersh, L.A. Mijares, G. Lanier, J. Lewis, G. Yap, A. Chen, A. Sher, C.S. Duckett, R. Ahmed, P.L. Schwartzberg, Altered lymphocyte responses and cytokine production in mice deficient in the X-linked lymphoproliferative disease gene 
SH2D1A/DSHP/SAP, Proceedings of the National Academy of Sciences of the United States of America, 98 (2001) 7449-7454.

[46] J.L. Cannons, L.J. Yu, B. Hill, L.A. Mijares, D. Dombroski, K.E. Nichols, A. Antonellis, G.A. Koretzky, K. Gardner, P.L. Schwartzberg, SAP regulates T(H)2 differentiation and PKC-theta-mediated activation of NF-kappaB1, Immunity, 21 (2004) 693-706.

[47] M. Morra, R.A. Barrington, A.C. Abadia-Molina, S. Okamoto, A. Julien, C. Gullo, A. Kalsy, M.J. Edwards, G. Chen, R. Spolski, W.J. Leonard, B.T. Huber, P. Borrow, C.A. Biron, A.R. Satoskar, M.C. Carroll, C. Terhorst, Defective B cell responses in the absence of SH2D1A, Proceedings of the National Academy of Sciences of the United States of America, 102 (2005) 4819-4823.

[48] S. Crotty, E.N. Kersh, J. Cannons, P.L. Schwartzberg, R. Ahmed, SAP is required for generating long-term humoral immunity, Nature, 421 (2003) 282-287.

[49] J.D. Hron, L. Caplan, A.J. Gerth, P.L. Schwartzberg, S.L. Peng, SH2D1A regulates T-dependent humoral autoimmunity, The Journal of experimental medicine, 200 (2004) 261-266.

[50] A. Malbran, L. Belmonte, B. Ruibal-Ares, P. Bare, I. Massud, C. Parodi, M. Felippo, R. Hodinka, K. Haines, K.E. Nichols, M.M. de Bracco, Loss of circulating CD27+ memory B cells and CCR4+ T cells occurring in association with elevated EBV loads in XLP patients surviving primary EBV infection, Blood, 103 (2004) 1625-1631.

[51] C.S. Ma, N.J. Hare, K.E. Nichols, L. Dupre, G. Andolfi, M.G. Roncarolo, S. Adelstein, P.D. Hodgkin, S.G. Tangye, Impaired humoral immunity in X-linked 
lymphoproliferative disease is associated with defective IL-10 production by CD4+ T cells, The Journal of clinical investigation, 115 (2005) 1049-1059.

[52] C. Detre, B. Yigit, M. Keszei, W. Castro, E.M. Magelky, C. Terhorst, SAP modulates B cell functions in a genetic background-dependent manner, Immunology letters, $153(2013)$ 15-21.

[53] L. Dupre, G. Andolfi, S.G. Tangye, R. Clementi, F. Locatelli, M. Arico, A. Aiuti, M.G. Roncarolo, SAP controls the cytolytic activity of CD8+ T cells against EBV-infected cells, Blood, 105 (2005) 4383-4389.

[54] G. Chen, A.K. Tai, M. Lin, F. Chang, C. Terhorst, B.T. Huber, Signaling lymphocyte activation molecule-associated protein is a negative regulator of the CD8 $\mathrm{T}$ cell response in mice, Journal of immunology, 175 (2005) 2212-2218.

[55] I.J. Kim, C.E. Burkum, T. Cookenham, P.L. Schwartzberg, D.L. Woodland, M.A. Blackman, Perturbation of B cell activation in SLAM-associated protein-deficient mice is associated with changes in gammaherpesvirus latency reservoirs, Journal of immunology, 178 (2007) 1692-1701.

[56] K.E. Nichols, J. Hom, S.Y. Gong, A. Ganguly, C.S. Ma, J.L. Cannons, S.G. Tangye, P.L. Schwartzberg, G.A. Koretzky, P.L. Stein, Regulation of NKT cell development by SAP, the protein defective in XLP, Nature medicine, 11 (2005) 340-345.

[57] B. Chung, A. Aoukaty, J. Dutz, C. Terhorst, R. Tan, Signaling lymphocytic activation molecule-associated protein controls NKT cell functions, Journal of immunology, 174 (2005) 3153-3157.

[58] B. Pasquier, L. Yin, M.C. Fondaneche, F. Relouzat, C. Bloch-Queyrat, N. Lambert, A. Fischer, G. de Saint-Basile, S. Latour, Defective NKT cell development in mice and 
humans lacking the adapter SAP, the X-linked lymphoproliferative syndrome gene product, The Journal of experimental medicine, 201 (2005) 695-701.

[59] S.R. Peck, H.E. Ruley, Ly108: a new member of the mouse CD2 family of cell surface proteins, Immunogenetics, 52 (2000) 63-72.

[60] A.E. Wandstrat, C. Nguyen, N. Limaye, A.Y. Chan, S. Subramanian, X.H. Tian, Y.S. Yim, A. Pertsemlidis, H.R. Garner, Jr., L. Morel, E.K. Wakeland, Association of extensive polymorphisms in the SLAM/CD2 gene cluster with murine lupus, Immunity, 21 (2004) 769-780.

[61] M. Keszei, C. Detre, S.T. Rietdijk, P. Munoz, X. Romero, S.B. Berger, S. Calpe, G. Liao, W. Castro, A. Julien, Y.Y. Wu, D.M. Shin, J. Sancho, M. Zubiaur, H.C. Morse, 3rd, L. Morel, P. Engel, N. Wang, C. Terhorst, A novel isoform of the Ly108 gene ameliorates murine lupus, The Journal of experimental medicine, 208 (2011) 811-822.

[62] A. Veillette, SLAM-family receptors: immune regulators with or without SAPfamily adaptors, Cold Spring Harbor perspectives in biology, 2 (2010) a002469.

[63] J.L. Cannons, S.G. Tangye, P.L. Schwartzberg, SLAM family receptors and SAP adaptors in immunity, Annual review of immunology, 29 (2011) 665-705.

[64] C. Li, C. Iosef, C.Y. Jia, V.K. Han, S.S. Li, Dual functional roles for the X-linked lymphoproliferative syndrome gene product SAP/SH2D1A in signaling through the signaling lymphocyte activation molecule (SLAM) family of immune receptors, The Journal of biological chemistry, 278 (2003) 3852-3859.

[65] S. Latour, R. Roncagalli, R. Chen, M. Bakinowski, X. Shi, P.L. Schwartzberg, D. Davidson, A. Veillette, Binding of SAP SH2 domain to FynT SH3 domain reveals a 
novel mechanism of receptor signalling in immune regulation, Nature cell biology, 5 (2003) 149-154.

[66] R.M. Flaig, S. Stark, C. Watzl, Cutting edge: NTB-A activates NK cells via homophilic interaction, Journal of immunology, 172 (2004) 6524-6527.

[67] J.L. Cannons, H. Qi, K.T. Lu, M. Dutta, J. Gomez-Rodriguez, J. Cheng, E.K. Wakeland, R.N. Germain, P.L. Schwartzberg, Optimal germinal center responses require a multistage $\mathrm{T}$ cell: $\mathrm{B}$ cell adhesion process involving integrins, SLAMassociated protein, and CD84, Immunity, 32 (2010) 253-265.

[68] K. Griewank, C. Borowski, S. Rietdijk, N. Wang, A. Julien, D.G. Wei, A.A. Mamchak, C. Terhorst, A. Bendelac, Homotypic interactions mediated by Slamf1 and Slamf6 receptors control NKT cell lineage development, Immunity, 27 (2007) 751762.

[69] M. Falco, E. Marcenaro, E. Romeo, F. Bellora, D. Marras, F. Vely, G. Ferracci, L. Moretta, A. Moretta, C. Bottino, Homophilic interaction of NTBA, a member of the CD2 molecular family: induction of cytotoxicity and cytokine release in human NK cells, European journal of immunology, 34 (2004) 1663-1672.

[70] W. Korver, S. Singh, S. Liu, X. Zhao, S. Yonkovich, A. Sweeney, K. Anton, W.E. Lomas, 3rd, R. Greenwood, A. Smith, D.H. Tran, P. Shinkawa, M. Jimenez, P. Yeung, G. Aguilar, S. Palencia, P. Vatta, M. Mueller, X. Zhan, E.M. Newton, Y. Liu, J. Zhao, P. Emtage, M.D. Levy, E.D. Hsi, W.D. Funk, A. Abo, The lymphoid cell surface receptor NTB-A: a novel monoclonal antibody target for leukaemia and lymphoma therapeutics, British journal of haematology, 137 (2007) 307-318. 
[71] N. Perez-Carmona, D. Farre, P. Martinez-Vicente, C. Terhorst, P. Engel, A. Angulo, Signaling Lymphocytic Activation Molecule Family Receptor Homologs in New World Monkey Cytomegaloviruses, Journal of virology, 89 (2015) 1132311336.

[72] A.H. Shah, B. Sowrirajan, Z.B. Davis, J.P. Ward, E.M. Campbell, V. Planelles, E. Barker, Degranulation of natural killer cells following interaction with HIV-1infected cells is hindered by downmodulation of NTB-A by Vpu, Cell host \& microbe, 8 (2010) 397-409.

[73] A. Duev-Cohen, Y. Bar-On, A. Glasner, O. Berhani, Y. Ophir, F. Levi-Schaffer, M. Mandelboim, O. Mandelboim, The human 2B4 and NTB-A receptors bind the influenza viral hemagglutinin and co-stimulate NK cell cytotoxicity, Oncotarget, 7 (2016) 13093-13105.

[74] P.J. Lucas, I. Negishi, K. Nakayama, L.E. Fields, D.Y. Loh, Naive CD28-deficient T cells can initiate but not sustain an in vitro antigen-specific immune response, Journal of immunology, 154 (1995) 5757-5768.

[75] A. Shahinian, K. Pfeffer, K.P. Lee, T.M. Kundig, K. Kishihara, A. Wakeham, K. Kawai, P.S. Ohashi, C.B. Thompson, T.W. Mak, Differential T cell costimulatory requirements in CD28-deficient mice, Science, 261 (1993) 609-612.

[76] P.A. Valdez, H. Wang, D. Seshasayee, M. van Lookeren Campagne, A. Gurney, W.P. Lee, I.S. Grewal, NTB-A, a new activating receptor in $\mathrm{T}$ cells that regulates autoimmune disease, The Journal of biological chemistry, 279 (2004) 18662-18669. 
[77] H.P. wang N, Yigit B, Zhao H, O_Keeffe MS, Sage P, Sharpe A, Terhorst C, Negative Regulation of humoral immunity due to interplay between the SLAMF1, SLAMF5, and SLAMF6 receptors, Front. Immunol., 6 (2015).

[78] N. Wang, M. Keszei, P. Halibozek, B. Yigit, P. Engel, C. Terhorst, Slamf6 negatively regulates autoimmunity, Clinical immunology, 173 (2016) 19-26.

[79] R. Kageyama, J.L. Cannons, F. Zhao, I. Yusuf, C. Lao, M. Locci, P.L. Schwartzberg, S. Crotty, The receptor Ly108 functions as a SAP adaptor-dependent on-off switch for T cell help to B cells and NKT cell development, Immunity, 36 (2012) 986-1002.

[80] D. Howie, F.S. Laroux, M. Morra, A.R. Satoskar, L.E. Rosas, W.A. Faubion, A. Julien, S. Rietdijk, A.J. Coyle, C. Fraser, C. Terhorst, Cutting edge: the SLAM family receptor Ly108 controls T cell and neutrophil functions, Journal of immunology, 174 (2005) 5931-5935.

[81] A.L. Snow, P. Pandiyan, L. Zheng, S.M. Krummey, M.J. Lenardo, The power and the promise of restimulation-induced cell death in human immune diseases, Immunological reviews, 236 (2010) 68-82.

[82] A.L. Snow, R.A. Marsh, S.M. Krummey, P. Roehrs, L.R. Young, K. Zhang, J. van Hoff, D. Dhar, K.E. Nichols, A.H. Filipovich, H.C. Su, J.J. Bleesing, M.J. Lenardo, Restimulation-induced apoptosis of T cells is impaired in patients with X-linked lymphoproliferative disease caused by SAP deficiency, The Journal of clinical investigation, 119 (2009) 2976-2989.

[83] G. Katz, S.M. Krummey, S.E. Larsen, J.R. Stinson, A.L. Snow, SAP facilitates recruitment and activation of LCK at NTB-A receptors during restimulation-induced cell death, Journal of immunology, 192 (2014) 4202-4209. 
[84] R. Uzana, G. Eisenberg, Y. Sagi, S. Frankenburg, S. Merims, N. Amariglio, E. Yefenof, T. Peretz, A. Machlenkin, M. Lotem, Trogocytosis is a gateway to characterize functional diversity in melanoma-specific CD8+ T cell clones, Journal of immunology, 188 (2012) 632-640.

[85] E. Joly, D. Hudrisier, What is trogocytosis and what is its purpose?, Nature immunology, 4 (2003) 815.

[86] R. Sharifi, J.C. Sinclair, K.C. Gilmour, P.D. Arkwright, C. Kinnon, A.J. Thrasher, H.B. Gaspar, SAP mediates specific cytotoxic T-cell functions in X-linked lymphoproliferative disease, Blood, 103 (2004) 3821-3827.

[87] A.D. Hislop, U. Palendira, A.M. Leese, P.D. Arkwright, P.S. Rohrlich, S.G. Tangye, H.B. Gaspar, A.C. Lankester, A. Moretta, A.B. Rickinson, Impaired Epstein-Barr virusspecific CD8+ T-cell function in X-linked lymphoproliferative disease is restricted to SLAM family-positive B-cell targets, Blood, 116 (2010) 3249-3257.

[88] U. Palendira, C. Low, A. Chan, A.D. Hislop, E. Ho, T.G. Phan, E. Deenick, M.C. Cook, D.S. Riminton, S. Choo, R. Loh, F. Alvaro, C. Booth, H.B. Gaspar, A. Moretta, R. Khanna, A.B. Rickinson, S.G. Tangye, Molecular pathogenesis of EBV susceptibility in XLP as revealed by analysis of female carriers with heterozygous expression of SAP, PLoS biology, 9 (2011) e1001187.

[89] H. Qi, J.L. Cannons, F. Klauschen, P.L. Schwartzberg, R.N. Germain, SAPcontrolled T-B cell interactions underlie germinal centre formation, Nature, 455 (2008) 764-769. 
[90] F. Zhao, J.L. Cannons, M. Dutta, G.M. Griffiths, P.L. Schwartzberg, Positive and negative signaling through SLAM receptors regulate synapse organization and thresholds of cytolysis, Immunity, 36 (2012) 1003-1016.

[91] C. Bottino, M. Falco, S. Parolini, E. Marcenaro, R. Augugliaro, S. Sivori, E. Landi, R. Biassoni, L.D. Notarangelo, L. Moretta, A. Moretta, NTB-A [correction of GNTB-A], a novel SH2D1A-associated surface molecule contributing to the inability of natural killer cells to kill Epstein-Barr virus-infected B cells in X-linked lymphoproliferative disease, The Journal of experimental medicine, 194 (2001) 235-246.

[92] P. Eissmann, C. Watzl, Molecular analysis of NTB-A signaling: a role for EAT-2 in NTB-A-mediated activation of human NK cells, Journal of immunology, 177 (2006) $3170-3177$.

[93] S. Stark, C. Watzl, 2B4 (CD244), NTB-A and CRACC (CS1) stimulate cytotoxicity but no proliferation in human NK cells, International immunology, 18 (2006) 241247.

[94] N. Wu, M.C. Zhong, R. Roncagalli, L.A. Perez-Quintero, H. Guo, Z. Zhang, C. Lenoir, Z. Dong, S. Latour, A. Veillette, A hematopoietic cell-driven mechanism involving SLAMF6 receptor, SAP adaptors and SHP-1 phosphatase regulates NK cell education, Nature immunology, 17 (2016) 387-396.

[95] A. Bendelac, P.B. Savage, L. Teyton, The biology of NKT cells, Annual review of immunology, 25 (2007) 297-336.

[96] T.K. Starr, S.C. Jameson, K.A. Hogquist, Positive and negative selection of T cells, Annual review of immunology, 21 (2003) 139-176. 
[97] L.J. Berg, Signaling pathways that regulate $\mathrm{T}$ cell development and differentiation, Journal of immunology, 189 (2012) 5487-5488.

[98] L.J. Berg, Signalling through TEC kinases regulates conventional versus innate CD8(+) T-cell development, Nature reviews. Immunology, 7 (2007) 479-485.

[99] C. Detre, M. Keszei, N. Garrido-Mesa, K. Kis-Toth, W. Castro, A.F. Agyemang, N. Veerapen, G.S. Besra, M.C. Carroll, G.C. Tsokos, N. Wang, E.A. Leadbetter, C. Terhorst, SAP expression in invariant NKT cells is required for cognate help to support B-cell responses, Blood, 120 (2012) 122-129.

[100] N. Wang, A. Satoskar, W. Faubion, D. Howie, S. Okamoto, S. Feske, C. Gullo, K. Clarke, M.R. Sosa, A.H. Sharpe, C. Terhorst, The cell surface receptor SLAM controls T cell and macrophage functions, The Journal of experimental medicine, 199 (2004) 1255-1264.

[101] M. Dutta, Z.J. Kraus, J. Gomez-Rodriguez, S.H. Hwang, J.L. Cannons, J. Cheng, S.Y. Lee, D.L. Wiest, E.K. Wakeland, P.L. Schwartzberg, A role for Ly108 in the induction of promyelocytic zinc finger transcription factor in developing thymocytes, Journal of immunology, 190 (2013) 2121-2128.

[102] D. Kovalovsky, O.U. Uche, S. Eladad, R.M. Hobbs, W. Yi, E. Alonzo, K. Chua, M. Eidson, H.J. Kim, J.S. Im, P.P. Pandolfi, D.B. Sant'Angelo, The BTB-zinc finger transcriptional regulator PLZF controls the development of invariant natural killer T cell effector functions, Nature immunology, 9 (2008) 1055-1064.

[103] A.K. Savage, M.G. Constantinides, J. Han, D. Picard, E. Martin, B. Li, O. Lantz, A. Bendelac, The transcription factor PLZF directs the effector program of the NKT cell lineage, Immunity, 29 (2008) 391-403. 
[104] J. De Calisto, N. Wang, G. Wang, B. Yigit, P. Engel, C. Terhorst, SAP-Dependent and -Independent Regulation of Innate $\mathrm{T}$ Cell Development Involving SLAMF Receptors, Front Immunol, 5 (2014) 186.

[105] G.C. Tsokos, Systemic lupus erythematosus, The New England journal of medicine, 365 (2011) 2110-2121.

[106] V.R. Moulton, A. Suarez-Fueyo, E. Meidan, H. Li, M. Mizui, G.C. Tsokos, Pathogenesis of Human Systemic Lupus Erythematosus: A Cellular Perspective, Trends in molecular medicine, 23 (2017) 615-635.

[107] N. Limaye, K.A. Belobrajdic, A.E. Wandstrat, F. Bonhomme, S.V. Edwards, E.K. Wakeland, Prevalence and evolutionary origins of autoimmune susceptibility alleles in natural mouse populations, Genes and immunity, 9 (2008) 61-68.

[108] L. Morel, K.R. Blenman, B.P. Croker, E.K. Wakeland, The major murine systemic lupus erythematosus susceptibility locus, Sle1, is a cluster of functionally related genes, Proceedings of the National Academy of Sciences of the United States of America, 98 (2001) 1787-1792.

[109] R.H. Shmerling, Autoantibodies in systemic lupus erythematosus--there before you know it, The New England journal of medicine, 349 (2003) 1499-1500.

[110] M.C. Zhong, A. Veillette, Control of T lymphocyte signaling by Ly108, a signaling lymphocytic activation molecule family receptor implicated in autoimmunity, The Journal of biological chemistry, 283 (2008) 19255-19264.

[111] K.R. Kumar, L. Li, M. Yan, M. Bhaskarabhatla, A.B. Mobley, C. Nguyen, J.M. Mooney, J.D. Schatzle, E.K. Wakeland, C. Mohan, Regulation of B cell tolerance by the lupus susceptibility gene Ly108, Science, 312 (2006) 1665-1669. 
[112] M. Keszei, C. Detre, W. Castro, E. Magelky, M. O'Keeffe, K. Kis-Toth, G.C. Tsokos, N. Wang, C. Terhorst, Expansion of an osteopontin-expressing T follicular helper cell subset correlates with autoimmunity in B6.Sle1b mice and is suppressed by the H1isoform of the Slamf6 receptor, FASEB journal : official publication of the Federation of American Societies for Experimental Biology, 27 (2013) 3123-3131.

[113] P. Bachireddy, U.E. Burkhardt, M. Rajasagi, C.J. Wu, Haematological malignancies: at the forefront of immunotherapeutic innovation, Nature reviews. Cancer, 15 (2015) 201-215.

[114] E. Ten Hacken, J.A. Burger, Microenvironment interactions and B-cell receptor signaling in Chronic Lymphocytic Leukemia: Implications for disease pathogenesis and treatment, Biochimica et biophysica acta, 1863 (2016) 401-413.

[115] N. Chiorazzi, K.R. Rai, M. Ferrarini, Chronic lymphocytic leukemia, The New England journal of medicine, 352 (2005) 804-815.

[116] R.N. Damle, F. Ghiotto, A. Valetto, E. Albesiano, F. Fais, X.J. Yan, C.P. Sison, S.L. Allen, J. Kolitz, P. Schulman, V.P. Vinciguerra, P. Budde, J. Frey, K.R. Rai, M. Ferrarini, N. Chiorazzi, B-cell chronic lymphocytic leukemia cells express a surface membrane phenotype of activated, antigen-experienced B lymphocytes, Blood, 99 (2002) 40874093.

[117] U. Klein, Y. Tu, G.A. Stolovitzky, M. Mattioli, G. Cattoretti, H. Husson, A. Freedman, G. Inghirami, L. Cro, L. Baldini, A. Neri, A. Califano, R. Dalla-Favera, Gene expression profiling of B cell chronic lymphocytic leukemia reveals a homogeneous phenotype related to memory B cells, The Journal of experimental medicine, 194 (2001) 1625-1638. 
[118] M. Seifert, L. Sellmann, J. Bloehdorn, F. Wein, S. Stilgenbauer, J. Durig, R. Kuppers, Cellular origin and pathophysiology of chronic lymphocytic leukemia, The Journal of experimental medicine, 209 (2012) 2183-2198.

[119] R.N. Damle, T. Wasil, F. Fais, F. Ghiotto, A. Valetto, S.L. Allen, A. Buchbinder, D. Budman, K. Dittmar, J. Kolitz, S.M. Lichtman, P. Schulman, V.P. Vinciguerra, K.R. Rai, M. Ferrarini, N. Chiorazzi, Ig V gene mutation status and CD38 expression as novel prognostic indicators in chronic lymphocytic leukemia, Blood, 94 (1999) 18401847.

[120] T.J. Hamblin, Z. Davis, A. Gardiner, D.G. Oscier, F.K. Stevenson, Unmutated Ig $\mathrm{V}(\mathrm{H})$ genes are associated with a more aggressive form of chronic lymphocytic leukemia, Blood, 94 (1999) 1848-1854.

[121] H. Dohner, S. Stilgenbauer, A. Benner, E. Leupolt, A. Krober, L. Bullinger, K. Dohner, M. Bentz, P. Lichter, Genomic aberrations and survival in chronic lymphocytic leukemia, The New England journal of medicine, 343 (2000) 19101916.

[122] U. Klein, M. Lia, M. Crespo, R. Siegel, Q. Shen, T. Mo, A. Ambesi-Impiombato, A. Califano, A. Migliazza, G. Bhagat, R. Dalla-Favera, The DLEU2/miR-15a/16-1 cluster controls B cell proliferation and its deletion leads to chronic lymphocytic leukemia, Cancer cell, 17 (2010) 28-40.

[123] T. Zenz, D. Mertens, R. Kuppers, H. Dohner, S. Stilgenbauer, From pathogenesis to treatment of chronic lymphocytic leukaemia, Nature reviews. Cancer, 10 (2010) 37-50. 
[124] M. Crespo, F. Bosch, N. Villamor, B. Bellosillo, D. Colomer, M. Rozman, S. Marce, A. Lopez-Guillermo, E. Campo, E. Montserrat, ZAP-70 expression as a surrogate for immunoglobulin-variable-region mutations in chronic lymphocytic leukemia, The New England journal of medicine, 348 (2003) 1764-1775.

[125] A. Wiestner, A. Rosenwald, T.S. Barry, G. Wright, R.E. Davis, S.E. Henrickson, H. Zhao, R.E. Ibbotson, J.A. Orchard, Z. Davis, M. Stetler-Stevenson, M. Raffeld, D.C. Arthur, G.E. Marti, W.H. Wilson, T.J. Hamblin, D.G. Oscier, L.M. Staudt, ZAP-70 expression identifies a chronic lymphocytic leukemia subtype with unmutated immunoglobulin genes, inferior clinical outcome, and distinct gene expression profile, Blood, 101 (2003) 4944-4951.

[126] G. Fabbri, S. Rasi, D. Rossi, V. Trifonov, H. Khiabanian, J. Ma, A. Grunn, M. Fangazio, D. Capello, S. Monti, S. Cresta, E. Gargiulo, F. Forconi, A. Guarini, L. Arcaini, M. Paulli, L. Laurenti, L.M. Larocca, R. Marasca, V. Gattei, D. Oscier, F. Bertoni, C.G. Mullighan, R. Foa, L. Pasqualucci, R. Rabadan, R. Dalla-Favera, G. Gaidano, Analysis of the chronic lymphocytic leukemia coding genome: role of NOTCH1 mutational activation, The Journal of experimental medicine, 208 (2011) 1389-1401.

[127] X.S. Puente, M. Pinyol, V. Quesada, L. Conde, G.R. Ordonez, N. Villamor, G. Escaramis, P. Jares, S. Bea, M. Gonzalez-Diaz, L. Bassaganyas, T. Baumann, M. Juan, M. Lopez-Guerra, D. Colomer, J.M. Tubio, C. Lopez, A. Navarro, C. Tornador, M. Aymerich, M. Rozman, J.M. Hernandez, D.A. Puente, J.M. Freije, G. Velasco, A. Gutierrez-Fernandez, D. Costa, A. Carrio, S. Guijarro, A. Enjuanes, L. Hernandez, J. Yague, P. Nicolas, C.M. Romeo-Casabona, H. Himmelbauer, E. Castillo, J.C. Dohm, S. de Sanjose, M.A. Piris, E. de Alava, J. San Miguel, R. Royo, J.L. Gelpi, D. Torrents, M. 
Orozco, D.G. Pisano, A. Valencia, R. Guigo, M. Bayes, S. Heath, M. Gut, P. Klatt, J. Marshall, K. Raine, L.A. Stebbings, P.A. Futreal, M.R. Stratton, P.J. Campbell, I. Gut, A. Lopez-Guillermo, X. Estivill, E. Montserrat, C. Lopez-Otin, E. Campo, Whole-genome sequencing identifies recurrent mutations in chronic lymphocytic leukaemia, Nature, 475 (2011) 101-105.

[128] F. Damm, E. Mylonas, A. Cosson, K. Yoshida, V. Della Valle, E. Mouly, M. Diop, L. Scourzic, Y. Shiraishi, K. Chiba, H. Tanaka, S. Miyano, Y. Kikushige, F. Davi, J. Lambert, D. Gautheret, H. Merle-Beral, L. Sutton, P. Dessen, E. Solary, K. Akashi, W. Vainchenker, T. Mercher, N. Droin, S. Ogawa, F. Nguyen-Khac, O.A. Bernard, Acquired initiating mutations in early hematopoietic cells of CLL patients, Cancer discovery, 4 (2014) 1088-1101.

[129] L. Wang, M.S. Lawrence, Y. Wan, P. Stojanov, C. Sougnez, K. Stevenson, L. Werner, A. Sivachenko, D.S. DeLuca, L. Zhang, W. Zhang, A.R. Vartanov, S.M. Fernandes, N.R. Goldstein, E.G. Folco, K. Cibulskis, B. Tesar, Q.L. Sievers, E. Shefler, S. Gabriel, N. Hacohen, R. Reed, M. Meyerson, T.R. Golub, E.S. Lander, D. Neuberg, J.R. Brown, G. Getz, C.J. Wu, SF3B1 and other novel cancer genes in chronic lymphocytic leukemia, The New England journal of medicine, 365 (2011) 2497-2506.

[130] P. Panayiotidis, D. Jones, K. Ganeshaguru, L. Foroni, A.V. Hoffbrand, Human bone marrow stromal cells prevent apoptosis and support the survival of chronic lymphocytic leukaemia cells in vitro, British journal of haematology, 92 (1996) 97103. 
[131] L. Lagneaux, A. Delforge, D. Bron, C. De Bruyn, P. Stryckmans, Chronic lymphocytic leukemic B cells but not normal B cells are rescued from apoptosis by contact with normal bone marrow stromal cells, Blood, 91 (1998) 2387-2396.

[132] J.A. Burger, N. Tsukada, M. Burger, N.J. Zvaifler, M. Dell'Aquila, T.J. Kipps, Blood-derived nurse-like cells protect chronic lymphocytic leukemia B cells from spontaneous apoptosis through stromal cell-derived factor-1, Blood, 96 (2000) $2655-2663$.

[133] A. Burkle, M. Niedermeier, A. Schmitt-Graff, W.G. Wierda, M.J. Keating, J.A. Burger, Overexpression of the CXCR5 chemokine receptor, and its ligand, CXCL13 in B-cell chronic lymphocytic leukemia, Blood, 110 (2007) 3316-3325.

[134] T. Vaisitti, S. Aydin, D. Rossi, F. Cottino, L. Bergui, G. D'Arena, L. Bonello, A.L. Horenstein, P. Brennan, C. Pepper, G. Gaidano, F. Malavasi, S. Deaglio, CD38 increases CXCL12-mediated signals and homing of chronic lymphocytic leukemia cells, Leukemia, 24 (2010) 958-969.

[135] S. Deaglio, S. Aydin, M.M. Grand, T. Vaisitti, L. Bergui, G. D'Arena, G. Chiorino, F. Malavasi, CD38/CD31 interactions activate genetic pathways leading to proliferation and migration in chronic lymphocytic leukemia cells, Molecular medicine, 16 (2010) 87-91.

[136] J.A. Burger, M.P. Quiroga, E. Hartmann, A. Burkle, W.G. Wierda, M.J. Keating, A. Rosenwald, High-level expression of the T-cell chemokines CCL3 and CCL4 by chronic lymphocytic leukemia B cells in nurselike cell cocultures and after BCR stimulation, Blood, 113 (2009) 3050-3058. 
[137] J.A. Burger, N. Chiorazzi, B cell receptor signaling in chronic lymphocytic leukemia, Trends in immunology, 34 (2013) 592-601.

[138] A.L. Shaffer, 3rd, R.M. Young, L.M. Staudt, Pathogenesis of human B cell lymphomas, Annual review of immunology, 30 (2012) 565-610.

[139] D.J. Allsup, A.S. Kamiguti, K. Lin, P.D. Sherrington, Z. Matrai, J.R. Slupsky, J.C. Cawley, M. Zuzel, B-cell receptor translocation to lipid rafts and associated signaling differ between prognostically important subgroups of chronic lymphocytic leukemia, Cancer research, 65 (2005) 7328-7337.

[140] M. Binder, F. Muller, A. Jackst, B. Lechenne, M. Pantic, U. Bacher, C. Zu Eulenburg, H. Veelken, R. Mertelsmann, R. Pasqualini, W. Arap, M. Trepel, B-cell receptor epitope recognition correlates with the clinical course of chronic lymphocytic leukemia, Cancer, 117 (2011) 1891-1900.

[141] M. Muzio, B. Apollonio, C. Scielzo, M. Frenquelli, I. Vandoni, V. Boussiotis, F. Caligaris-Cappio, P. Ghia, Constitutive activation of distinct BCR-signaling pathways in a subset of CLL patients: a molecular signature of anergy, Blood, 112 (2008) 188195.

[142] B. Apollonio, C. Scielzo, M.T. Bertilaccio, E. Ten Hacken, L. Scarfo, P. Ranghetti, F. Stevenson, G. Packham, P. Ghia, M. Muzio, F. Caligaris-Cappio, Targeting B-cell anergy in chronic lymphocytic leukemia, Blood, 121 (2013) 3879-3888, S38713878.

[143] S. Kitada, J.M. Zapata, M. Andreeff, J.C. Reed, Bryostatin and CD40-ligand enhance apoptosis resistance and induce expression of cell survival genes in B-cell 
chronic lymphocytic leukaemia, British journal of haematology, 106 (1999) 9951004.

[144] I. Tinhofer, I. Marschitz, M. Kos, T. Henn, A. Egle, A. Villunger, R. Greil, Differential sensitivity of CD4+ and CD8+ T lymphocytes to the killing efficacy of Fas (Apo-1/CD95) ligand+ tumor cells in B chronic lymphocytic leukemia, Blood, 91 (1998) 4273-4281.

[145] C.L. Goolsby, M. Kuchnio, W.G. Finn, L. Peterson, Expansions of clonal and oligoclonal T cells in B-cell chronic lymphocytic leukemia are primarily restricted to the CD3(+)CD8(+) T-cell population, Cytometry, 42 (2000) 188-195.

[146] D. Serrano, J. Monteiro, S.L. Allen, J. Kolitz, P. Schulman, S.M. Lichtman, A. Buchbinder, V.P. Vinciguerra, N. Chiorazzi, P.K. Gregersen, Clonal expansion within the CD4+CD57+ and CD8+CD57+ $\mathrm{T}$ cell subsets in chronic lymphocytic leukemia, Journal of immunology, 158 (1997) 1482-1489.

[147] H. Mellstedt, A. Choudhury, T and B cells in B-chronic lymphocytic leukaemia: Faust, Mephistopheles and the pact with the Devil, Cancer immunology, immunotherapy : CII, 55 (2006) 210-220.

[148] G. Gorgun, T.A. Holderried, D. Zahrieh, D. Neuberg, J.G. Gribben, Chronic lymphocytic leukemia cells induce changes in gene expression of CD4 and CD8 T cells, The Journal of clinical investigation, 115 (2005) 1797-1805.

[149] G. D'Arena, L. Laurenti, M.M. Minervini, S. Deaglio, L. Bonello, L. De Martino, L. De Padua, L. Savino, M. Tarnani, V. De Feo, N. Cascavilla, Regulatory T-cell number is increased in chronic lymphocytic leukemia patients and correlates with progressive disease, Leukemia research, 35 (2011) 363-368. 
[150] K. Giannopoulos, M. Schmitt, M. Kowal, P. Wlasiuk, A. Bojarska-Junak, J. Chen, J. Rolinski, A. Dmoszynska, Characterization of regulatory T cells in patients with Bcell chronic lymphocytic leukemia, Oncology reports, 20 (2008) 677-682.

[151] A. Dasgupta, M. Mahapatra, R. Saxena, A study for proposal of use of regulatory $\mathrm{T}$ cells as a prognostic marker and establishing an optimal threshold level for their expression in chronic lymphocytic leukemia, Leukemia \& lymphoma, 56 (2015) 1831-1838.

[152] E.J. Wherry, T cell exhaustion, Nature immunology, 12 (2011) 492-499.

[153] A.G. Ramsay, A.J. Johnson, A.M. Lee, G. Gorgun, R. Le Dieu, W. Blum, J.C. Byrd, J.G. Gribben, Chronic lymphocytic leukemia T cells show impaired immunological synapse formation that can be reversed with an immunomodulating drug, The Journal of clinical investigation, 118 (2008) 2427-2437.

[154] M. Palma, G. Gentilcore, K. Heimersson, F. Mozaffari, B. Nasman-Glaser, E. Young, R. Rosenquist, L. Hansson, A. Osterborg, H. Mellstedt, T cells in chronic lymphocytic leukemia display dysregulated expression of immune checkpoints and activation markers, Haematologica, 102 (2017) 562-572.

[155] C. Nunes, R. Wong, M. Mason, C. Fegan, S. Man, C. Pepper, Expansion of a CD8(+)PD-1(+) replicative senescence phenotype in early stage CLL patients is associated with inverted CD4:CD8 ratios and disease progression, Clinical cancer research : an official journal of the American Association for Cancer Research, 18 (2012) 678-687.

[156] S.H. Tonino, P.J. van de Berg, S.L. Yong, I.J. ten Berge, M.J. Kersten, R.A. van Lier, M.H. van Oers, A.P. Kater, Expansion of effector T cells associated with decreased 
PD-1 expression in patients with indolent B cell lymphomas and chronic lymphocytic leukemia, Leukemia \& lymphoma, 53 (2012) 1785-1794.

[157] J.R. Gothert, L. Eisele, L. Klein-Hitpass, S. Weber, M.L. Zesewitz, L. Sellmann, A. Roth, H. Pircher, U. Duhrsen, J. Durig, Expanded CD8+ T cells of murine and human CLL are driven into a senescent KLRG1+ effector memory phenotype, Cancer immunology, immunotherapy : CII, 62 (2013) 1697-1709.

[158] N. Khan, N. Shariff, M. Cobbold, R. Bruton, J.A. Ainsworth, A.J. Sinclair, L. Nayak, P.A. Moss, Cytomegalovirus seropositivity drives the CD8 $\mathrm{T}$ cell repertoire toward greater clonality in healthy elderly individuals, Journal of immunology, 169 (2002) 1984-1992.

[159] W.J. Mackus, F.N. Frakking, A. Grummels, L.E. Gamadia, G.J. De Bree, D. Hamann, R.A. Van Lier, M.H. Van Oers, Expansion of CMV-specific CD8+CD45RA+CD27- T cells in B-cell chronic lymphocytic leukemia, Blood, 102 (2003) 1057-1063.

[160] B. Pourgheysari, R. Bruton, H. Parry, L. Billingham, C. Fegan, J. Murray, P. Moss, The number of cytomegalovirus-specific CD4+ T cells is markedly expanded in patients with B-cell chronic lymphocytic leukemia and determines the total CD4+ Tcell repertoire, Blood, 116 (2010) 2968-2974.

[161] J.C. Riches, J.K. Davies, F. McClanahan, R. Fatah, S. Iqbal, S. Agrawal, A.G. Ramsay, J.G. Gribben, T cells from CLL patients exhibit features of T-cell exhaustion but retain capacity for cytokine production, Blood, 121 (2013) 1612-1621.

[162] G.D. te Raa, M.F. Pascutti, J.J. Garcia-Vallejo, E. Reinen, E.B. Remmerswaal, I.J. ten Berge, R.A. van Lier, E. Eldering, M.H. van Oers, S.H. Tonino, A.P. Kater, CMV- 
specific CD8+ T-cell function is not impaired in chronic lymphocytic leukemia, Blood, 123 (2014) 717-724.

[163] D. Brusa, S. Serra, M. Coscia, D. Rossi, G. D'Arena, L. Laurenti, O. Jaksic, G. Fedele, G. Inghirami, G. Gaidano, F. Malavasi, S. Deaglio, The PD-1/PD-L1 axis contributes to T-cell dysfunction in chronic lymphocytic leukemia, Haematologica, 98 (2013) 953-963.

[164] A.G. Ramsay, A.J. Clear, R. Fatah, J.G. Gribben, Multiple inhibitory ligands induce impaired T-cell immunologic synapse function in chronic lymphocytic leukemia that can be blocked with lenalidomide: establishing a reversible immune evasion mechanism in human cancer, Blood, 120 (2012) 1412-1421.

[165] R. Jitschin, M. Braun, M. Buttner, K. Dettmer-Wilde, J. Bricks, J. Berger, M.J. Eckart, S.W. Krause, P.J. Oefner, K. Le Blanc, A. Mackensen, D. Mougiakakos, CLL-cells induce IDOhi CD14+HLA-DRlo myeloid-derived suppressor cells that inhibit T-cell responses and promote TRegs, Blood, 124 (2014) 750-760.

[166] F.J. Gassner, N. Zaborsky, K. Catakovic, S. Rebhandl, M. Huemer, A. Egle, T.N. Hartmann, R. Greil, R. Geisberger, Chronic lymphocytic leukaemia induces an exhausted T cell phenotype in the TCL1 transgenic mouse model, British journal of haematology, 170 (2015) 515-522.

[167] A. Bresin, L. D'Abundo, M.G. Narducci, M.T. Fiorenza, C.M. Croce, M. Negrini, G. Russo, TCL1 transgenic mouse model as a tool for the study of therapeutic targets and microenvironment in human B-cell chronic lymphocytic leukemia, Cell death \& disease, 7 (2016) e2071. 
[168] F. McClanahan, J.C. Riches, S. Miller, W.P. Day, E. Kotsiou, D. Neuberg, C.M. Croce, M. Capasso, J.G. Gribben, Mechanisms of PD-L1/PD-1-mediated CD8 T-cell dysfunction in the context of aging-related immune defects in the Emicro-TCL1 CLL mouse model, Blood, 126 (2015) 212-221.

[169] R.R. Jenq, M.R. van den Brink, Allogeneic haematopoietic stem cell transplantation: individualized stem cell and immune therapy of cancer, Nature reviews. Cancer, 10 (2010) 213-221.

[170] I.F. Khouri, R. Bassett, N. Poindexter, S. O'Brien, C.E. Bueso-Ramos, Y. Hsu, A. Ferrajoli, M.J. Keating, R. Champlin, M. Fernandez-Vina, Nonmyeloablative allogeneic stem cell transplantation in relapsed/refractory chronic lymphocytic leukemia: long-term follow-up, prognostic factors, and effect of human leukocyte histocompatibility antigen subtype on outcome, Cancer, 117 (2011) 4679-4688.

[171] C.J. Wu, J. Ritz, Induction of tumor immunity following allogeneic stem cell transplantation, Advances in immunology, 90 (2006) 133-173.

[172] L.A. Honigberg, A.M. Smith, M. Sirisawad, E. Verner, D. Loury, B. Chang, S. Li, Z. Pan, D.H. Thamm, R.A. Miller, J.J. Buggy, The Bruton tyrosine kinase inhibitor PCI32765 blocks B-cell activation and is efficacious in models of autoimmune disease and B-cell malignancy, Proceedings of the National Academy of Sciences of the United States of America, 107 (2010) 13075-13080.

[173] S.E. Herman, A.L. Gordon, E. Hertlein, A. Ramanunni, X. Zhang, S. Jaglowski, J. Flynn, J. Jones, K.A. Blum, J.J. Buggy, A. Hamdy, A.J. Johnson, J.C. Byrd, Bruton tyrosine kinase represents a promising therapeutic target for treatment of chronic 
lymphocytic leukemia and is effectively targeted by PCI-32765, Blood, 117 (2011) 6287-6296.

[174] S. Ponader, S.S. Chen, J.J. Buggy, K. Balakrishnan, V. Gandhi, W.G. Wierda, M.J. Keating, S. O'Brien, N. Chiorazzi, J.A. Burger, The Bruton tyrosine kinase inhibitor PCI-32765 thwarts chronic lymphocytic leukemia cell survival and tissue homing in vitro and in vivo, Blood, 119 (2012) 1182-1189.

[175] S.E. Herman, C.U. Niemann, M. Farooqui, J. Jones, R.Z. Mustafa, A. Lipsky, N. Saba, S. Martyr, S. Soto, J. Valdez, J.A. Gyamfi, I. Maric, K.R. Calvo, L.B. Pedersen, C.H. Geisler, D. Liu, G.E. Marti, G. Aue, A. Wiestner, Ibrutinib-induced lymphocytosis in patients with chronic lymphocytic leukemia: correlative analyses from a phase II study, Leukemia, 28 (2014) 2188-2196.

[176] J.A. Dubovsky, K.A. Beckwith, G. Natarajan, J.A. Woyach, S. Jaglowski, Y. Zhong, J.D. Hessler, T.M. Liu, B.Y. Chang, K.M. Larkin, M.R. Stefanovski, D.L. Chappell, F.W. Frissora, L.L. Smith, K.A. Smucker, J.M. Flynn, J.A. Jones, L.A. Andritsos, K. Maddocks, A.M. Lehman, R. Furman, J. Sharman, A. Mishra, M.A. Caligiuri, A.R. Satoskar, J.J. Buggy, N. Muthusamy, A.J. Johnson, J.C. Byrd, Ibrutinib is an irreversible molecular inhibitor of ITK driving a Th1-selective pressure in T lymphocytes, Blood, 122 (2013) 2539-2549.

[177] Q. Yin, M. Sivina, H. Robins, E. Yusko, M. Vignali, S. O'Brien, M.J. Keating, A. Ferrajoli, Z. Estrov, N. Jain, W.G. Wierda, J.A. Burger, Ibrutinib Therapy Increases T Cell Repertoire Diversity in Patients with Chronic Lymphocytic Leukemia, Journal of immunology, 198 (2017) 1740-1747. 
[178] C.U. Niemann, S.E. Herman, I. Maric, J. Gomez-Rodriguez, A. Biancotto, B.Y. Chang, S. Martyr, M. Stetler-Stevenson, C.M. Yuan, K.R. Calvo, R.C. Braylan, J. Valdez, Y.S. Lee, D.H. Wong, J. Jones, C. Sun, G.E. Marti, M.Z. Farooqui, A. Wiestner, Disruption of in vivo Chronic Lymphocytic Leukemia Tumor-Microenvironment Interactions by Ibrutinib--Findings from an Investigator-Initiated Phase II Study, Clinical cancer research : an official journal of the American Association for Cancer Research, 22 (2016) 1572-1582.

[179] M. Podhorecka, A. Goracy, A. Szymczyk, M. Kowal, B. Ibanez, O. JankowskaLecka, A. Macheta, A. Nowaczynska, E. Drab-Urbanek, S. Chocholska, D. Jawniak, M. Hus, Changes in T-cell subpopulations and cytokine network during early period of ibrutinib therapy in chronic lymphocytic leukemia patients: the significant decrease in T regulatory cells number, Oncotarget, 8 (2017) 34661-34669.

[180] M. Long, K. Beckwith, P. Do, B.L. Mundy, A. Gordon, A.M. Lehman, K.J. Maddocks, C. Cheney, J.A. Jones, J.M. Flynn, L.A. Andritsos, F. Awan, J.A. Fraietta, C.H. June, M.V. Maus, J.A. Woyach, M.A. Caligiuri, A.J. Johnson, N. Muthusamy, J.C. Byrd, Ibrutinib treatment improves $\mathrm{T}$ cell number and function in CLL patients, The Journal of clinical investigation, 127 (2017) 3052-3064.

[181] K. Kondo, H. Shaim, P.A. Thompson, J.A. Burger, M. Keating, Z. Estrov, D. Harris, E. Kim, A. Ferrajoli, M. Daher, R. Basar, M. Muftuoglu, N. Imahashi, A. Alsuliman, C. Sobieski, E. Gokdemir, W. Wierda, N. Jain, E. Liu, E.J. Shpall, K. Rezvani, Ibrutinib modulates the immunosuppressive CLL microenvironment through STAT3mediated suppression of regulatory B-cell function and inhibition of the PD-1/PDL1 pathway, Leukemia, (2017). 
[182] S.E.M. Herman, A. Montraveta, C.U. Niemann, H. Mora-Jensen, M. Gulrajani, F. Krantz, R. Mantel, L.L. Smith, F. McClanahan, B.K. Harrington, D. Colomer, T. Covey, J.C. Byrd, R. Izumi, A. Kaptein, R. Ulrich, A.J. Johnson, B.J. Lannutti, A. Wiestner, J.A. Woyach, The Bruton Tyrosine Kinase (BTK) Inhibitor Acalabrutinib Demonstrates Potent On-Target Effects and Efficacy in Two Mouse Models of Chronic Lymphocytic Leukemia, Clinical cancer research : an official journal of the American Association for Cancer Research, 23 (2017) 2831-2841.

[183] V.K. Patel, B. Lamothe, M.L. Ayres, J. Gay, J.P. Cheung, K. Balakrishnan, C. Ivan, J. Morse, M. Nelson, M.J. Keating, W.G. Wierda, J.R. Marszalek, V. Gandhi, Pharmacodynamics and proteomic analysis of acalabrutinib therapy: similarity of on-target effects to ibrutinib and rationale for combination therapy, Leukemia, (2017).

[184] V. Patel, K. Balakrishnan, E. Bibikova, M. Ayres, M.J. Keating, W.G. Wierda, V. Gandhi, Comparison of Acalabrutinib, A Selective Bruton Tyrosine Kinase Inhibitor, with Ibrutinib in Chronic Lymphocytic Leukemia Cells, Clinical cancer research : an official journal of the American Association for Cancer Research, 23 (2017) 37343743.

[185] M. Hallek, K. Fischer, G. Fingerle-Rowson, A.M. Fink, R. Busch, J. Mayer, M. Hensel, G. Hopfinger, G. Hess, U. von Grunhagen, M. Bergmann, J. Catalano, P.L. Zinzani, F. Caligaris-Cappio, J.F. Seymour, A. Berrebi, U. Jager, B. Cazin, M. Trneny, A. Westermann, C.M. Wendtner, B.F. Eichhorst, P. Staib, A. Buhler, D. Winkler, T. Zenz, S. Bottcher, M. Ritgen, M. Mendila, M. Kneba, H. Dohner, S. Stilgenbauer, I. International Group of, G. German Chronic Lymphocytic Leukaemia Study, Addition 
of rituximab to fludarabine and cyclophosphamide in patients with chronic lymphocytic leukaemia: a randomised, open-label, phase 3 trial, Lancet, 376 (2010) 1164-1174.

[186] J.D. Hainsworth, Monoclonal antibody therapy in lymphoid malignancies, The oncologist, 5 (2000) 376-384.

[187] B. Eichhorst, T. Robak, E. Montserrat, P. Ghia, P. Hillmen, M. Hallek, C. Buske, E.G. Committee, Chronic lymphocytic leukaemia: ESMO Clinical Practice Guidelines for diagnosis, treatment and follow-up, Annals of oncology : official journal of the European Society for Medical Oncology, 26 Suppl 5 (2015) v78-84.

[188] M.P. Chao, Treatment challenges in the management of relapsed or refractory non-Hodgkin's lymphoma - novel and emerging therapies, Cancer management and research, 5 (2013) 251-269.

[189] E. Bachy, G. Salles, Are we nearing an era of chemotherapy-free management of indolent lymphoma?, Clinical cancer research : an official journal of the American Association for Cancer Research, 20 (2014) 5226-5239.

[190] P.V. Beum, M.A. Lindorfer, R.P. Taylor, Within peripheral blood mononuclear cells, antibody-dependent cellular cytotoxicity of rituximab-opsonized Daudi cells is promoted by NK cells and inhibited by monocytes due to shaving, Journal of immunology, 181 (2008) 2916-2924.

[191] P.V. Beum, E.M. Peek, M.A. Lindorfer, F.J. Beurskens, P.J. Engelberts, P.W. Parren, J.G. van de Winkel, R.P. Taylor, Loss of CD20 and bound CD20 antibody from opsonized B cells occurs more rapidly because of trogocytosis mediated by Fc 
receptor-expressing effector cells than direct internalization by the B cells, Journal of immunology, 187 (2011) 3438-3447.

[192] F. Da Roit, P.J. Engelberts, R.P. Taylor, E.C. Breij, G. Gritti, A. Rambaldi, M. Introna, P.W. Parren, F.J. Beurskens, J. Golay, Ibrutinib interferes with the cellmediated anti-tumor activities of therapeutic CD20 antibodies: implications for combination therapy, Haematologica, 100 (2015) 77-86.

[193] G. Pavlasova, M. Borsky, V. Seda, K. Cerna, J. Osickova, M. Doubek, J. Mayer, R. Calogero, M. Trbusek, S. Pospisilova, M.S. Davids, T.J. Kipps, J.R. Brown, M. Mraz, Ibrutinib inhibits CD20 upregulation on CLL B cells mediated by the CXCR4/SDF-1 axis, Blood, 128 (2016) 1609-1613.

[194] A.P. Kater, S.H. Tonino, A. Egle, A.G. Ramsay, How does lenalidomide target the chronic lymphocytic leukemia microenvironment?, Blood, 124 (2014) 2184-2189. [195] B.N. Lee, H. Gao, E.N. Cohen, X. Badoux, W.G. Wierda, Z. Estrov, S.H. Faderl, M.J. Keating, A. Ferrajoli, J.M. Reuben, Treatment with lenalidomide modulates T-cell immunophenotype and cytokine production in patients with chronic lymphocytic leukemia, Cancer, 117 (2011) 3999-4008.

[196] L. Wu, M. Adams, T. Carter, R. Chen, G. Muller, D. Stirling, P. Schafer, J.B. Bartlett, lenalidomide enhances natural killer cell and monocyte-mediated antibodydependent cellular cytotoxicity of rituximab-treated CD20+ tumor cells, Clinical cancer research : an official journal of the American Association for Cancer Research, 14 (2008) 4650-4657.

[197] X.C. Badoux, M.J. Keating, S. Wen, W.G. Wierda, S.M. O'Brien, S. Faderl, R. Sargent, J.A. Burger, A. Ferrajoli, Phase II study of lenalidomide and rituximab as 
salvage therapy for patients with relapsed or refractory chronic lymphocytic leukemia, Journal of clinical oncology : official journal of the American Society of Clinical Oncology, 31 (2013) 584-591.

[198] N. Jain, S. O'Brien, Targeted therapies for CLL: Practical issues with the changing treatment paradigm, Blood reviews, 30 (2016) 233-244.

[199] B. Yigit, P.J. Halibozek, S.S. Chen, M.S. O'Keeffe, J. Arnason, D. Avigan, V. Gattei, A. Bhan, O. Cen, R. Longnecker, N. Chiorazzi, N. Wang, P. Engel, C. Terhorst, A combination of an anti-SLAMF6 antibody and ibrutinib efficiently abrogates expansion of chronic lymphocytic leukemia cells, Oncotarget, 7 (2016) 2634626360.

[200] S.S. Chen, F. Batliwalla, N.E. Holodick, X.J. Yan, S. Yancopoulos, C.M. Croce, T.L. Rothstein, N. Chiorazzi, Autoantigen can promote progression to a more aggressive TCL1 leukemia by selecting variants with enhanced B-cell receptor signaling, Proceedings of the National Academy of Sciences of the United States of America, 110 (2013) E1500-1507.

[201] B. Yigit, N. Wang, S.S. Chen, N. Chiorazzi, C. Terhorst, Inhibition of reactive oxygen species limits expansion of chronic lymphocytic leukemia cells, Leukemia, 31 (2017) 2273-2276. 
Figure 1

a. Human

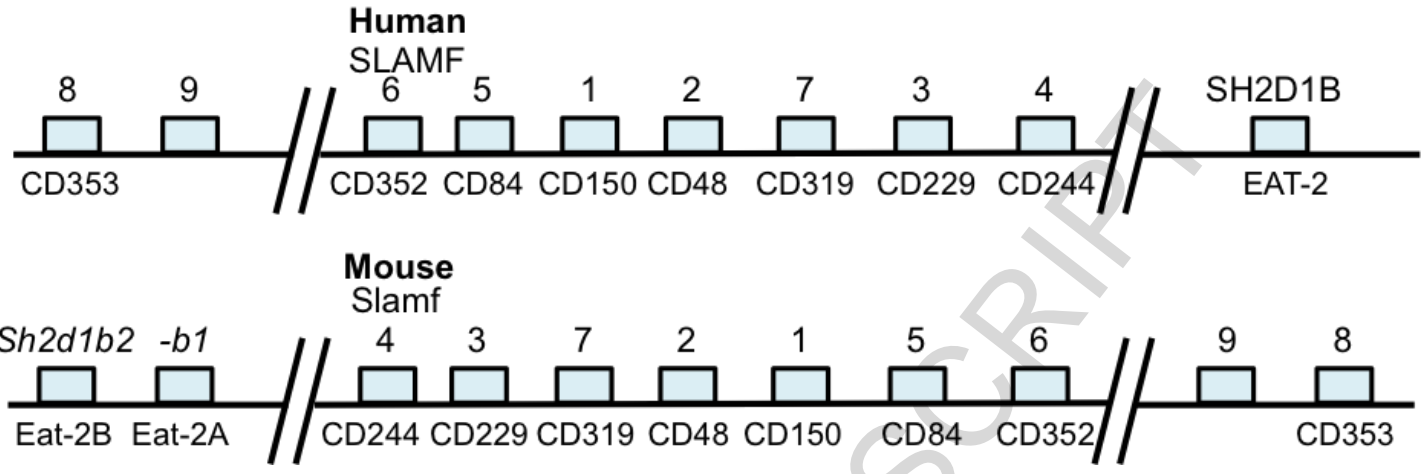

b.

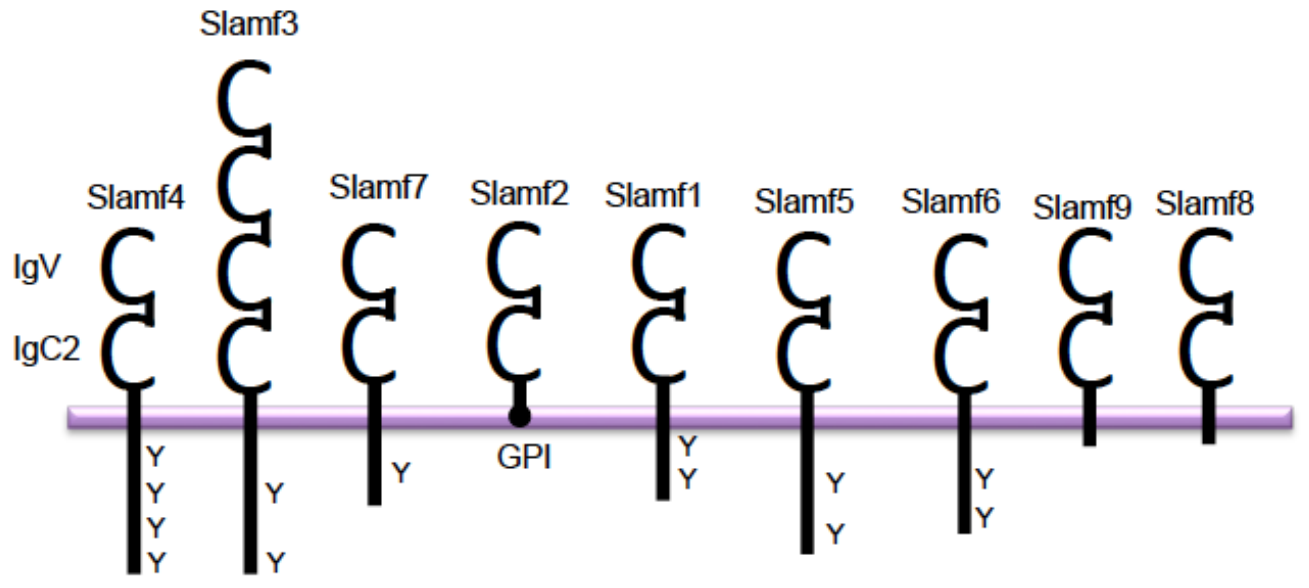


Figure 2

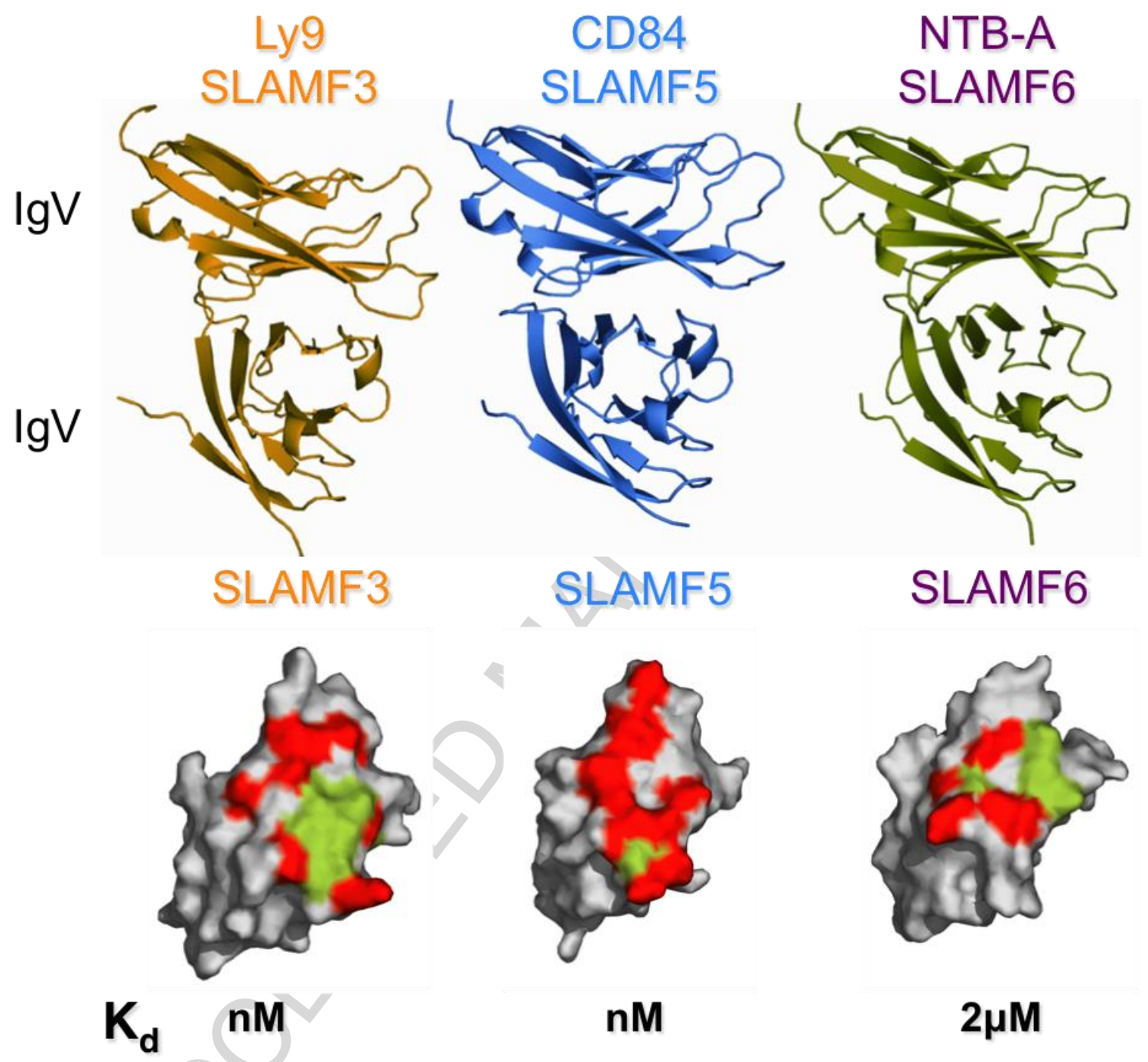


Figure 3

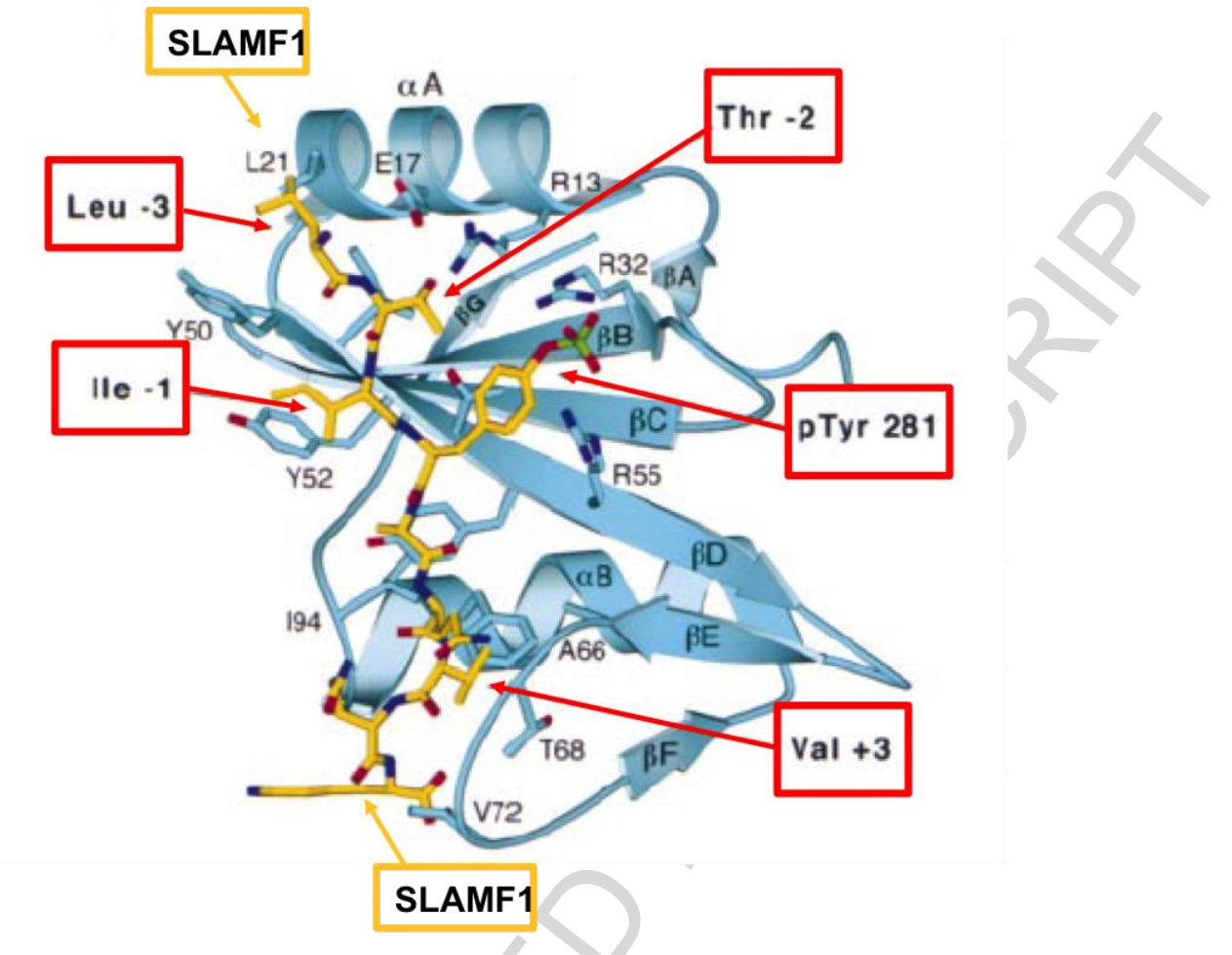


Figure 4

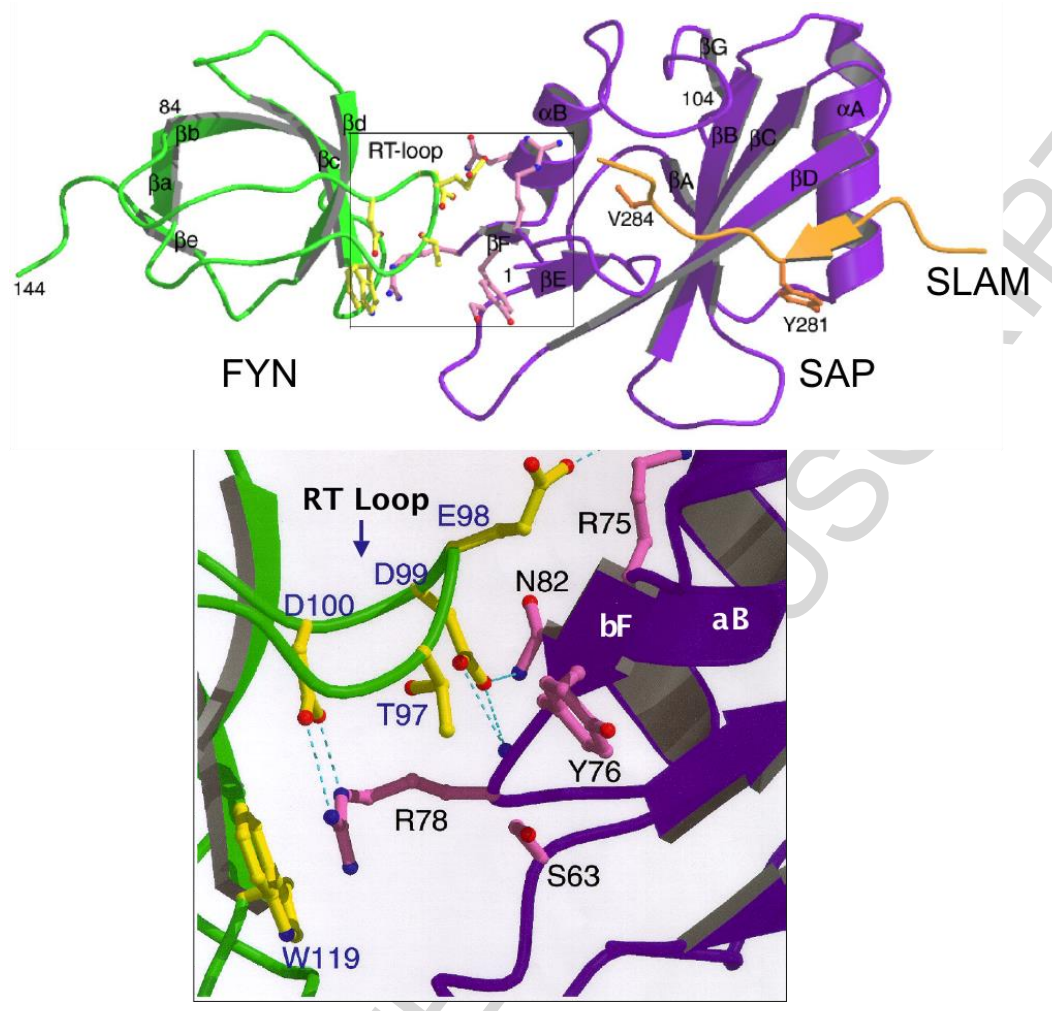


Figure 5

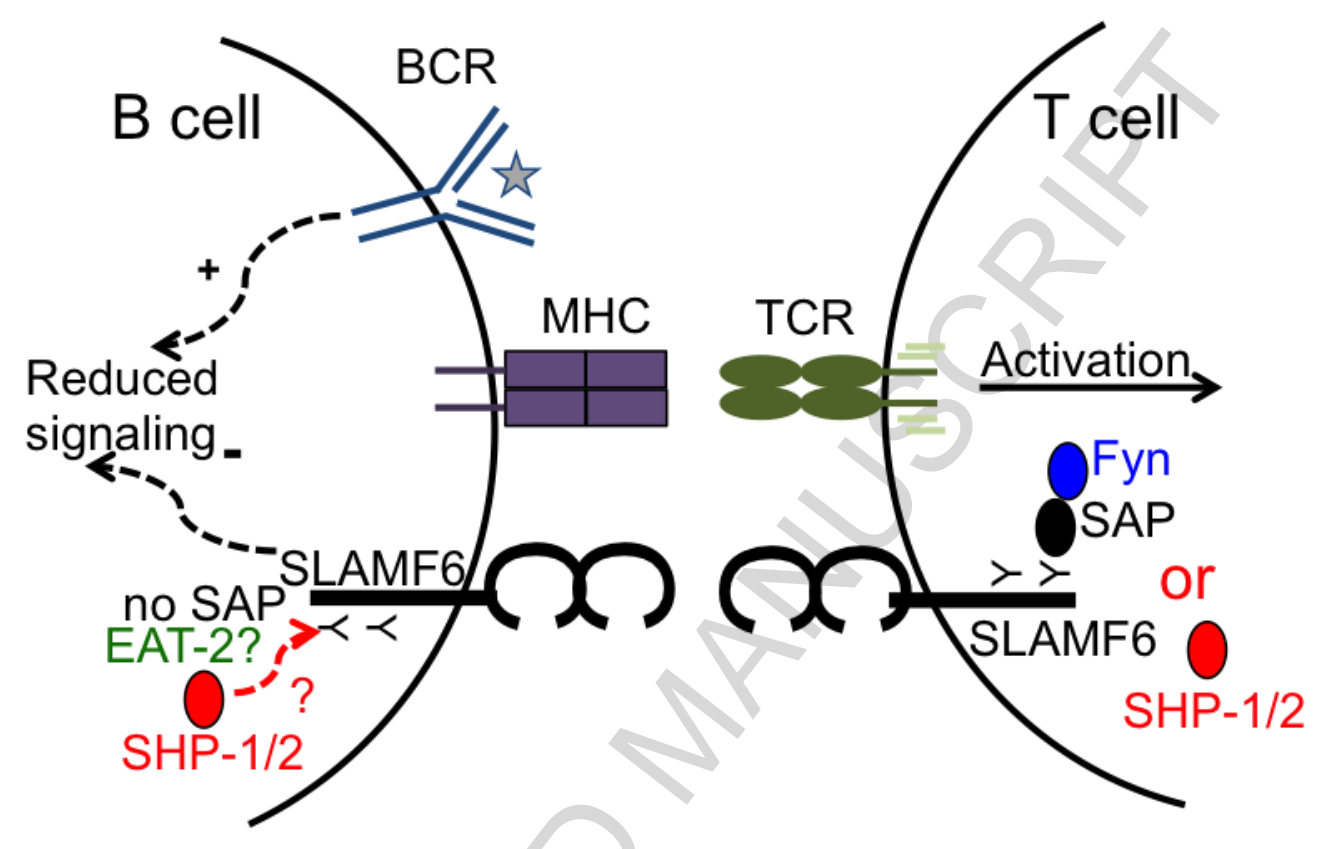


Figure 6

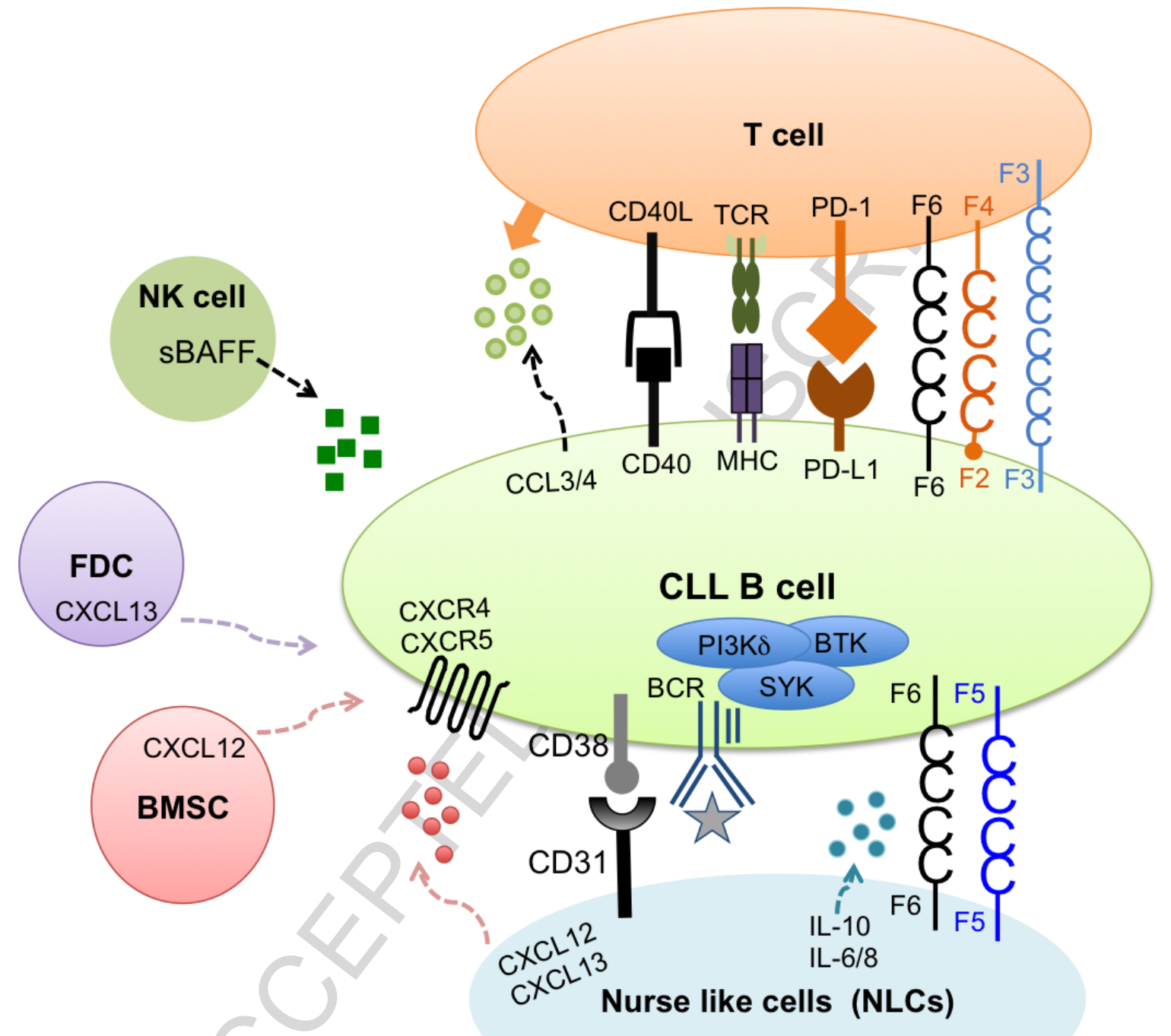


Figure 1. Signaling lymphocyte activation molecule family (SLAMF) of genes and protein. a. Organizational overview of SLAMF gene cluster on chromosome 1 in human and mouse. b. SLAMF members consist of an $\mathrm{lgV} / \mathrm{ggC2}$ ectodomain, which is duplicated in SLAMF3. While SLAMF2 and SLAMF4 bind each other, other SLAMF receptors are homophilic. Six members of the family contain varying lengths of cytoplasmic tail with ITSM motifs $(Y)$ that can recruit and bind the adaptors SAP and/or EAT-2.

Figure 2. Homophilic engagement of SLAMF3, SLAMF5 and SLAMF6 occurs via interactions of the $\lg V$ domains. Specificity of homophilic binding is determined by different surface characteristics. All three SLAMF receptors show different binding affinities. Green = hydrophobic, red= hydrophilic amino acids

Figure 3. Ribbon diagram showing SAP/SLAMF1 pY281 complex.

The bound SLAMF1 phosphopeptide is shown in a stick representation (yellow). Selected SAP residues that form the binding site are shown in blue. SLAMF1 residues $\mathrm{N}$-terminal to $\mathrm{pY} 281$ make additional interactions with SAP at pY -3 and $\mathrm{pY}-1$ (positions relative to pTyr281)[34, 35].

Figure 4. SAP couples Fyn to SLAMF receptors. SAP binds the Fyn SH3 domain through a non-canonical surface interaction (zoomed area). SLAM peptide binds SAP in a 3-pronged mode by via the b-strand of N-terminal, Tyr 281 and Val 284.

Figure 5. SLAMF6 localizes at the immune synapse. Ligation of SLAMF6 on a T cell recruits binding of SAP to the ITSM on the cytoplasmic tail. SAP recruits Fyn and 
induces activation. SAP has the highest affinity for cytoplasmic tail of SLAMs and blocks binding of SHP-1/2. In the absence of SAP, SHP-1/2 binds to cytoplasmic tail of SLAMF6 and induces negative signaling on T cells [79]. B cells do not express SAP. Whether EAT-2 is expressed or it blocks recruitment of SHP-1/2 is not known. However, ligation of SLAMF6 with an antibody in B cells appear to induce negative signals, which may be due to binding of SHP-1/2.

Figure 6. The CLL Microenvironment. Contact between CLL cells and nurse like cells (NLCs) is established by chemokine receptors and adhesion molecules expressed on CLL cells and ligands on NLCs. The CD38-CD31 axis promotes CLL survival. CXCR4/CXCL12 chemokine gradient allows shuffling of CLL cells between circulation and secondary lymphoid organs to receive survival and proliferation signals. SLAMF5 and SLAMF6 are expressed on the surface of NLCs (Yigit, unpublished data). The relevant contribution of these receptors to CLL survival requires further investigation. $T$ cells are another major contributor to CLL survival. Secretion of chemokines CCL3/4 by CLL cells attracts T cells nearby. CD40/CD40L interaction promotes survival and PD1/PD-L1 pathway favors immune evasion of CLL cells. NK cells, bone marrow stromal cells (BMSCs) and follicular dendritic cells (FDCs) also contribute to CLL survival. 
Highlights

- SLAMF6 is a cell surface receptor, expressed only on hematopoietic cells

- SLAMF6 receptor can positively or negatively regulate immune responses

- SLAMF6 have been implicated in autoimmunity and cancer and exploiting this receptor using monoclonal antibodies can help improve current treatment in various diseases 